\title{
A Review of Solar Collectors and Thermal Energy Storage in Solar Thermal Applications
}

\author{
Y. Tian ${ }^{\text {a }}$, C.Y. Zhao ${ }^{\mathrm{b}}$ \\ ${ }^{\text {a }}$ School of Engineering, University of Warwick, CV4 7AL Coventry, United Kingdom \\ Email: $\underline{\text { Y.Tian.4@warwick.ac.uk }}$ \\ ${ }^{\mathrm{b}}$ School of Mechanical Engineering, Shanghai Jiaotong University, 200240 Shanghai, China \\ Email: Changying.zhao@sjtu.edu.cn
}

\section{Article history:}

Received 24 July 2012

Revised 18 November 2012

Accepted 20 November 2012

Available online 22 December 2012

\section{Doi: http://dx.doi.org/10.1016/j.apenergy.2012.11.051}

\section{Cited as:}

Y Tian, CY Zhao. A review of solar collectors and thermal energy storage in solar thermal applications. Applied Energy 104 (2013): 538-553.

\begin{abstract}
Thermal applications are drawing increasing attention in the solar energy research field, due to their high performance in energy storage density and energy conversion efficiency. In these applications, solar collectors and thermal energy storage systems are the two core components. This paper focuses on the latest developments and advances in solar thermal applications, providing a review of solar collectors and thermal energy storage systems. Various types of solar collectors are reviewed and discussed, including both non-concentrating collectors (low temperature applications) and concentrating collectors (high temperature applications). These are studied in terms of optical optimisation, heat loss reduction, heat recuperation enhancement and different suntracking mechanisms. Various types of thermal energy storage systems are also reviewed and discussed, including sensible heat storage, latent heat storage, chemical storage and cascaded storage. They are studied in terms of design criteria, material selection and different heat transfer enhancement technologies. Last but not least, existing and future solar power stations are overviewed.
\end{abstract}




\section{Keywords:}

Solar collectors; Thermal energy storage; Heat transfer enhancement; Metal foam; PCM; Solar power stations.

\section{Highlights}

- The latest developments and advances in solar thermal applications are reviewed.

- Various types of solar collectors are studied, in terms of optical optimisation, heat loss reduction, heat recuperation enhancement and sun-tracking mechanisms.

- Various types of thermal energy storage systems are studied, in terms of design criteria, material selection and heat transfer enhancement technologies involved.

Existing and future solar power stations are reviewed.

\section{Table of Contents}

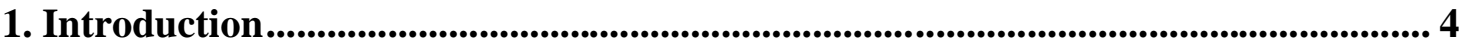

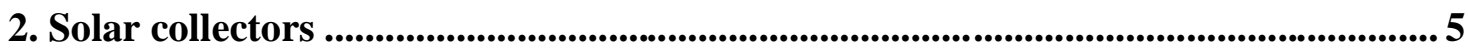

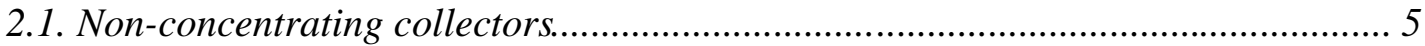

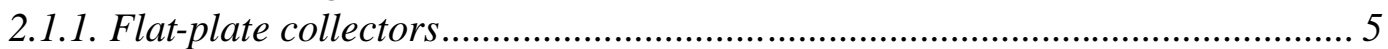

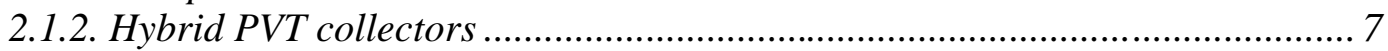

2.1.3. Enhanced hybrid PVT collectors - Bifacial PVT ........................................... 8

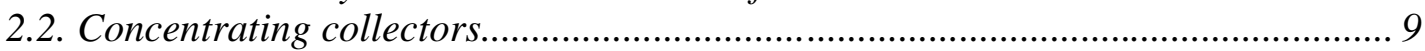

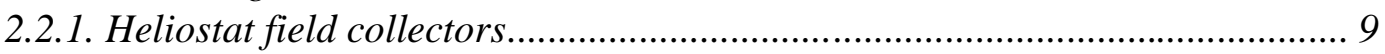

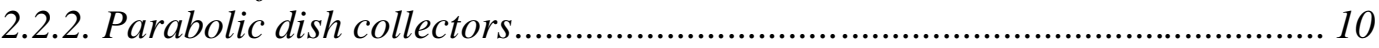

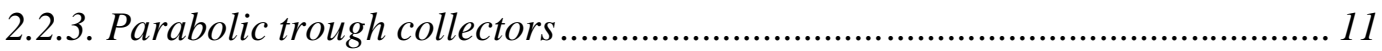

3. Solar thermal energy storage ...................................................................................12

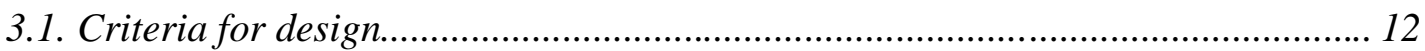

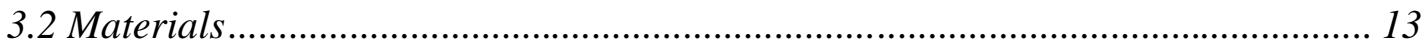

3.2.1. Sensible heat storage materials ................................................................... 13

3.2.2. Latent heat storage materials ….................................................................... 14

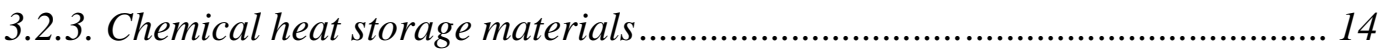

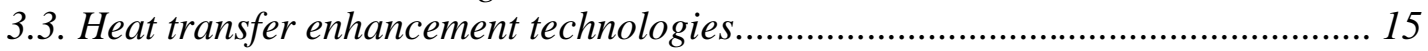

3.3.1. Incorporation of high-thermal conductivity enhancers .............................. 15

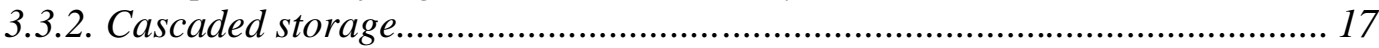

4. An overview of existing and future solar power stations .................................... 18

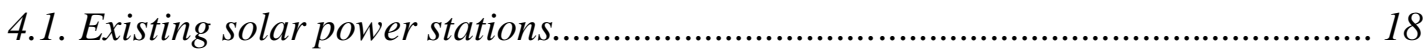

4.2. Solar power stations under construction ........................................................ 19

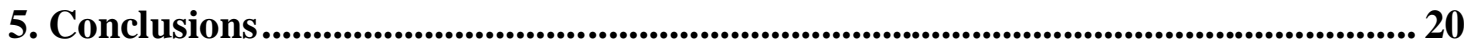

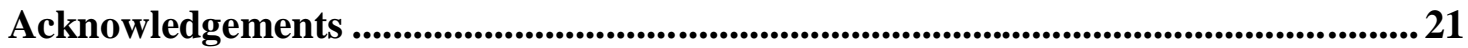




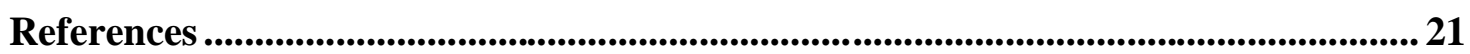

Table Captions ................................................................................................................................. 32

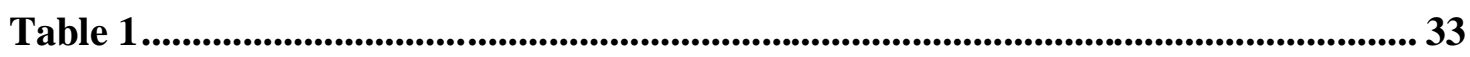

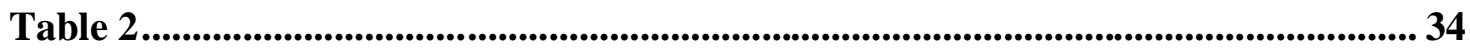

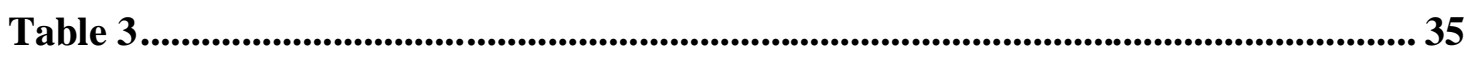

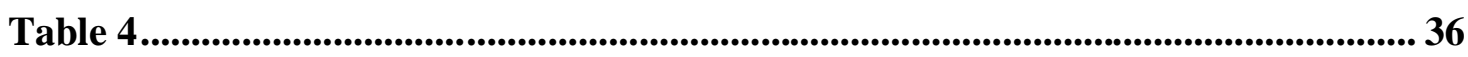

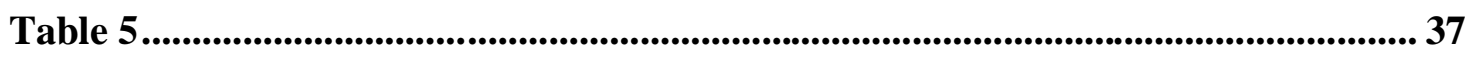

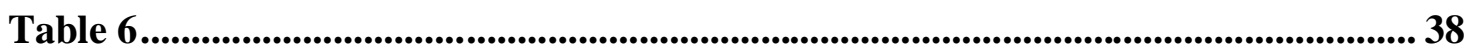

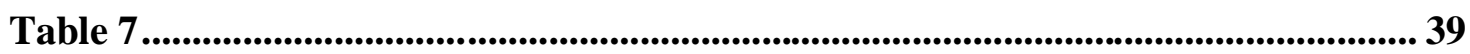

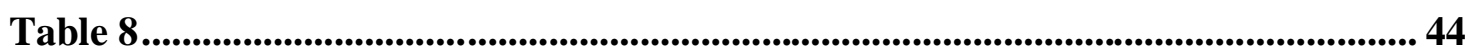

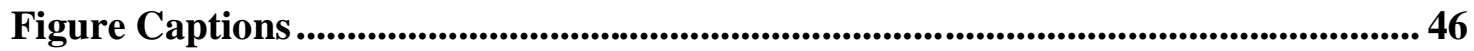

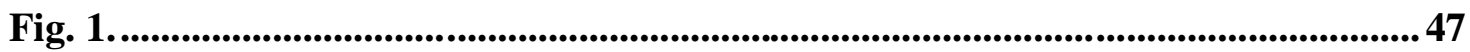

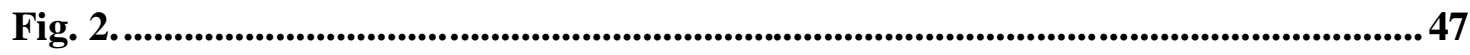

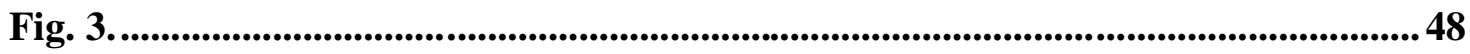

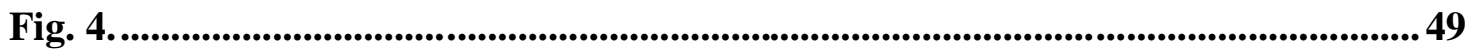

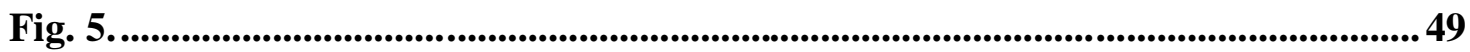

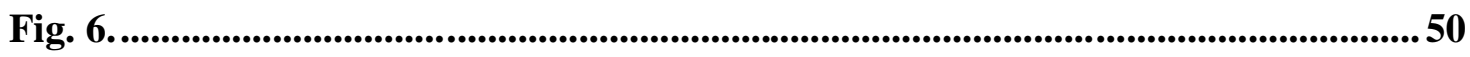

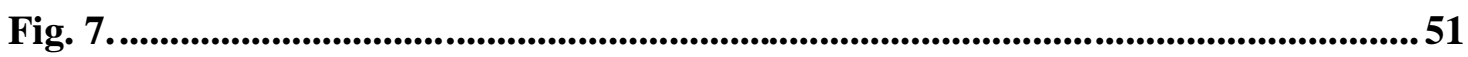

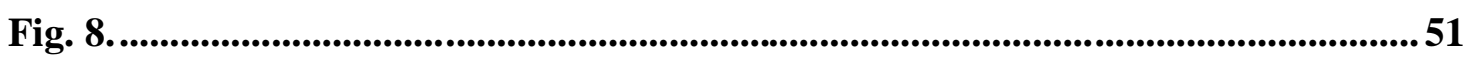

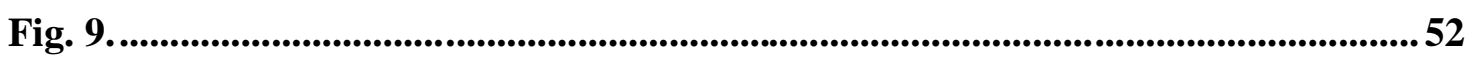

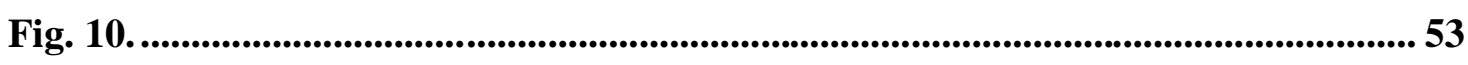

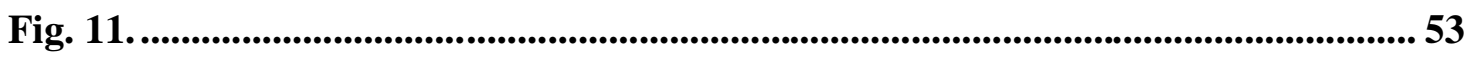

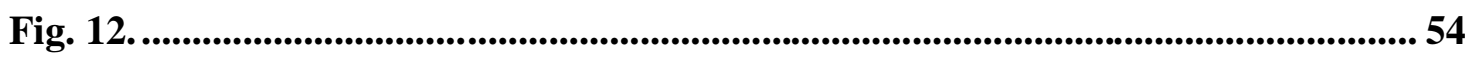

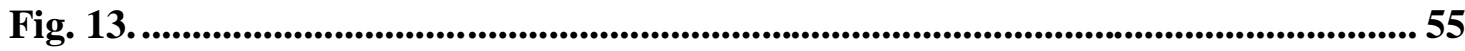




\section{Introduction}

$\mathrm{CO}_{2}$-induced global warming has become a pressing issue, and needs to be tackled. Efficient utilisation of renewable energy resources, especially solar energy, is increasingly being considered as a promising solution to global warming and a means of achieving a sustainable development for human beings. The Sun releases an enormous amount of radiation energy to its surroundings: $174 \mathrm{PW}\left(1 \mathrm{PW}=10^{15} \mathrm{~W}\right)$ at the upper atmosphere of the Earth [1]. When the energy arrives at the surface of the Earth, it has been attenuated twice by both the atmosphere $(6 \%$ by reflection and $16 \%$ by absorption [1]) and the clouds (20\% by reflection and $3 \%$ by absorption [1]), as shown in Fig. 1 [2]. Another 51\% (89 PW) of the total incoming solar radiation reaches the land and the oceans [1]. It is evident that, despite the attenuation, the total amount of solar energy available on the Earth is still of an enormous amount, but because it is of low-density and intermittency, it needs to be collected and stored efficiently.

Solar collectors and thermal energy storage components are the two kernel subsystems in solar thermal applications. Solar collectors need to have good optical performance (absorbing as much heat as possible) [3], whilst the thermal storage subsystems require high thermal storage density (small volume and low construction cost), excellent heat transfer rate (absorb and release heat at the required speed) and good long-term durability [4, 5]. In 2004, Kalogirou [6] reviewed several different types of solar thermal collectors that were in common use, and provided relative thermal analyses and practical applications of each type. However, the technologies involved in solar collectors have been much improved since that review was published, so that some of the latest collectors, such as PVT (Photovoltaic-Thermal) collectors, were not available in time for inclusion in [6]. These latest technologies are described in Section 2 of the present paper. In addition, most of existing review-type literature on thermal energy storage has been mainly restricted to low-temperature applications [4, 5, 7-9]. There are only a few papers addressing high-temperature thermal energy storage applications. These include Kenisarin [10], who reviewed a group of potential phase change materials (PCMs) used from $120{ }^{\circ} \mathrm{C}$ to $1000{ }^{\circ} \mathrm{C}$, and provided their thermal properties and Gil et al. [11], who reviewed the high-temperature thermal storage systems especially for power generation; they also listed desirable materials and thermal models that can be used. Updates of the latest developments in high-temperature thermal storage technologies are given in Section 3 of the present paper. 
This paper provides a review of various solar collectors and thermal storage methods, and is organised as follows:

- Solar collectors: non-concentrating collectors; concentrating collectors;

- High-temperature thermal energy storage: design criteria; materials; heat transfer enhancement technologies;

- An overview of existing and future solar power stations.

\section{Solar collectors}

A solar collector, the special energy exchanger, converts solar irradiation energy either to the thermal energy of the working fluid in solar thermal applications, or to the electric energy directly in PV (Photovoltaic) applications. For solar thermal applications, solar irradiation is absorbed by a solar collector as heat which is then transferred to its working fluid (air, water or oil). The heat carried by the working fluid can be used to either provide domestic hot water/heating, or to charge a thermal energy storage tank from which the heat can be drawn for use later (at night or cloudy days). For PV applications, a PV module not only converts solar irradiation directly into electric energy (usually with rather low efficiency), but it also produces plenty of waste heat, which can be recovered for thermal use by attaching PV board with recuperating tubes filled with carrier fluids.

Solar collectors are usually classified into two categories according to concentration ratios [3]: non-concentrating collectors and concentrating collectors. A non-concentrating collector has the same intercepting area as its absorbing area, whilst a sun-tracking concentrating solar collector usually has concave reflecting surfaces to intercept and focus the solar irradiation to a much smaller receiving area, resulting in an increased heat flux so that the thermodynamic cycle can achieve higher Carnot efficiency when working under higher temperatures.

\subsection{Non-concentrating collectors}

\subsubsection{Flat-plate collectors}

Flat-plate solar collectors are usually permanently fixed in position, and therefore need to be oriented appropriately. A typical flat-plate solar collector usually consists of glazing covers, absorber plates, insulation layers, recuperating tubes (filled with heat transfer fluids) and other auxiliaries. Glazing is made of single or multiple sheets of glass or other materials with high transmissivity of short-wave radiation and low transmissivity 
of long-wave radiation. It not only reduces convection losses from the absorber plate, but also reduces irradiation losses from the collector due to the greenhouse effect. Low-iron glass $[12,13]$ is regarded as a desirable glazing material due to its relatively high transmittance for solar radiation (approximately 0.85-0.87) [13] and an essentially zero transmittance for the long-wave thermal radiation $(5.0 \mu \mathrm{m}-50 \mu \mathrm{m})$. Hellstrom et al. [14] studied the impact of optical and thermal properties on the performance of flat-plate solar collectors, and found that adding a teflon film as second glazing increased overall performance by $5.6 \%$ at $50^{\circ} \mathrm{C}$, whilst installing a teflon honeycomb to reduce convection loss increased overall performance by $12.1 \%$. Further, antireflection treatment of the glazing cover increased the output by $6.5 \%$ at $50^{\circ} \mathrm{C}$ operating temperature.

The absorber plate is usually coated with blackened surface in order to absorb as much heat as possible; however various colour coatings have also been proposed in the literatures [15-17]. Desirable selective surfaces usually consist of a thin upper layer, which is highly absorbent to shortwave solar radiation but relatively transparent to longwave thermal radiation, and a thin lower layer that has a high reflectance and a low emittance for long-wave radiation. Such selective surfaces with a desirable optical performance usually have a high manufacturing cost, but several low-cost manufacturing ideas have also been proposed [18]. In addition, to further improve the thermal performance of a collector, heat loss from the absorber also needs to be reduced. Francia [19] found that a honeycomb insertion, which is made of transparent material and placed in the airspace between the glazing and the absorber, was beneficial to heat loss reduction.

The heat absorbed by the absorber plate needs to be transferred to working fluids rapidly to prevent system overheating [20]. Excellent heat transfer performance is necessary in solar receivers. Kumar and Reddy [21] investigated heat transfer enhancement of solar receivers with porous insertions and found that significant heat transfer improvement (64.3\%) was obtained. Lambert et al. [22] found that oscillating flow can significantly improve heat transfer by increasing thermal diffusivities of the working fluids in solar collectors. Ho et al. [23] employed a double-pass structure for solar receiver and achieved a better heat transfer rate. Ackermann et al. [24] conducted a computational investigation of the effects of internal fins on solar collector panels, concluding that heat transfer performance was increased by fins, and can be even further improved by decreasing the fin pitch and increasing thermal conductivities of fin materials. The study conducted by Sopian et al. [25] showed that the insertion of porous media in the second channel, as shown in Fig. 2, increased the outlet temperature, thereby increasing the thermal efficiency of the systems. In Fig. 2, $d_{l}$ is the upper channel depth 
and $d_{2}$ is the lower channel depth, both of which were varied in their study. Martinopoulos et al. [26] employed polycarbonate honeycombs to enhance heat transfer in solar collectors. Metal foams [27-29], which have high thermal conductivities and large specific surface area, were confirmed by many researchers to have abilities to significantly enhance heat transfer for phase change materials (PCMs). However, as far as the authors are aware, metal foams have not so far been examined for their potential capability to enhance heat transfer in recuperating tubes.

Relevant thermal analyses and numerical modelling for solar collectors have also been undertaken. Saha and Mahanta [30] investigated the thermodynamic optimisation of flat-plate solar collectors, with their model focusing on minimising all factors affecting entropy generation. Their study showed that an optimum operating regime existed. Farahat et al. [31] also conducted an optimisation analysis of combined energy and exergy for flat-plate solar collectors. They concluded that exergy efficiency increased when increasing optical efficiency and incident sunlight flux, but it decreased rapidly when increasing ambient temperature and wind speed. They also identified an optimum point for fluid inlet temperature. Further, pipe diameter was found to have only a minor effect on exergy efficiency. In addition, Selmi et al. [32] simulated heat transfer phenomena in flat-plate solar collectors using commercial CFD codes by considering the mixed heat transfer modes of conduction, convection and radiation between tube surface, glass cover, side walls and insulating base of the collector, and their results achieved good agreement with test data.

\subsubsection{Hybrid PVT collectors}

Hybrid photovoltaic/thermal (PVT) collectors [33] simultaneously convert solar energy into electricity and heat. A typical PVT collector consists of a PV module with peak efficiencies in the range of 5\%-20\% and an absorber plate (acting as a heat removal device) attached on the back of the PV module. The heat removal plate cools the PV module down to a suitable temperature for better electrical performance, and at the same time, it collects the waste heat, which can then be utilised for low temperature applications, such as domestic hot water production (showering and washing) and adsorption cooling systems [34].

Most of the significant amount of recent research on PVT collectors has been related to flat-plate collectors, with their investigation focusing on absorber plate and tube dimensions [35], fluid flow rates [36, 37], tank size [38], PV cell packing factor [39], use of amorphous silicon [40,41], use of metal fins [42], and multiple-passage configurations 
[43] (shown in Fig. 3) for the case of air collectors [44, 45]. The use of low concentration non-imaging optics with PVT has also received some attention [46, 47]. Figure 3 shows a comparison between four different PVT collectors (Hegazy [43]). It was found that under similar operational conditions, the Model I collector had the lowest performance and the Model III collector demanded the least fan power.

Performance comparisons between hybrid PVT collectors and conventional PV-only systems have also been conducted. All the results indicated that hybrid PVT systems can achieve increased energy conversion efficiency with potential cost benefits [48, 39, 49]. With detailed theoretical models for PVT collectors being developed, the complicated balance between thermal outputs and electrical outputs has been investigated $[35,50,37$, 51]. In addition, the exergy analysis of PVT collectors, based on the second Law of Thermodynamics, has been reported by Joshi and Tiwari [52].

\subsubsection{Enhanced hybrid PVT collectors - Bifacial PVT}

Hybrid PVT collectors can be classified into those that use water as the heat removal medium, and those that use air. Water is a desirable working fluid in hybrid PVT collectors, because of its high heat capacity and excellent optical properties. Tina et al. [53] tested a water-submerged solar panel system, and found that a $4 \mathrm{~cm}$-thick water layer reduced the optical reflection and the thermal drift in their system, which increased the photovoltaic efficiency by $15 \%$. There are two related reasons for such an efficiency boost. Firstly, water absorbs the sunlight mainly in the infrared region; secondly, water is fully transparent in the short-wavelength region, so that the long-wavelength irradiation can be absorbed by water to produce heat, and short-wavelength irradiation can be utilised by PV modules to produce electricity. Other researchers [54-56] have also confirmed such a natural compatibility of water to PV modules.

Figure 4 shows the optical transmission spectrum of a water layer with a thickness of $1.5 \mathrm{~cm}[54,55]$, as well as the absorption spectrum of a mono-crystalline layer of a PV solar cell with a thickness of $50 \mu \mathrm{m}[55,56]$. Figure 4 shows that water absorption only slightly affects the working region of a silicon PV cell (water transmissivity decreases at around 950nm), but it strongly absorbs the sunlight with the wavelengths above 1100nm. Therefore, the combination of a water-filled solar collector with silicon bifacial PVT hybrid module appears to be very promising.

Robles et al. [55] made a bifacial PV module covered by water, which can absorb long wavelength rays to produce heat and transmit short wavelength rays to PV module to produce electricity. The data for short-circuit is shown in Fig. 5. The lowest curve 
represents the short circuit current $I_{s c}$ of the rear face alone at different time in a day; the middle curve represents $I_{s c}$ for the front panel; the highest curve gives the total $I_{s c}$ for both faces of the PV module. The highest total value of $I_{s c}$ is $7.1 \mathrm{~A}$, and the corresponding values for the front and real face are 5.1A and $2 \mathrm{~A}$, respectively. They demonstrated that the bifacial PV module produced approximately 40\% more electric energy than a conventional PVT system, with no noticeable increase in the system cost.

However, the system efficiency in a bifacial PVT module can be further improved if the waste heat can be recovered to produce domestic hot water. To achieve higher efficiency, the optimisation of relevant flow passage design and heat transfer characteristics needs to be studied. The suggestion is that the double-flow passage (see Fig. 3) can be used in the bifacial PV module for further enhancement of the system efficiency. The double-flow passage not only removes excess heat more efficiently, but also saves the pump in the system which gives an even higher electricity output. Another problem for such a water-type PVT system is its difficulty to be used in extremely cold regions because freezing can easily break up the collectors [57]. A heat pipe-type PVT system was recently proposed by Pei et al. [57], and it was claimed that their system allowed heat transport almost without any temperature drop, and that corrosion can also be reduced.

\subsection{Concentrating collectors}

\subsubsection{Heliostat field collectors}

Concentrating collectors (usually equipped with sun-tracking techniques) have much higher concentration ratio than non-concentrating collectors. They can achieve higher temperatures of working fluids, meaning that it is possible to achieve a higher thermodynamic efficiency. The Heliostat Field Collector, also called the Central Receiver Collector, consists of a number of flat mirrors/heliostats. Due to the position change of the sun during the day, the whole array of mirrors/heliostats needs to have precise orientation to reflect incident solar lights to a common tower. The orientation of every individual heliostat is controlled by an automatic control system powered by altazimuth tracking technology. In addition, to place these heliostats with a higher overall optical efficiency, an optimised field layout design is needed. Wei et al. [58] proposed a technique which they called 'YNES' to design the optimised field layout.

An optimised field layout of heliostats can efficiently reflect solar light to the central tower, where a steam generator is located to absorb thermal energy and heat up water into the high-temperature and high-pressure steam (to drive turbine generators). The heat 
transfer fluid inside the steam generator can either be water/steam, liquid sodium, or molten salts (usually sodium nitrates or potassium nitrates), whilst the thermal storage media can be high temperature synthetic oil mixed with crushed rock, molten nitrate salt, or liquid sodium $[11,59]$.

Central tower solar collectors can be classified into external-type and cavity-type, depending on which kind of central receiver is used. The receiver used at the Solar One (Barstow, California, U.S.A.) is of the external type and as shown in Fig. 6 (a), it is located at the top of the central tower; it comprises 24 panels (receiver diameter: $7 \mathrm{~m}$ ), six of which are for preheating water and eighteen for producing steam. External receivers typically have a height to diameter ratio of $1: 1$ to $2: 1$. In order to reduce heat loss, the area of the receiver is usually designed to be as minimum as possible. However, the lower limit of the receiver area is determined by the maximum operating temperature of the heat exchange tubes and the heat removal capability of the heat transfer fluid, to protect heat transfer fluid from being overheated. The lower limit of the receiver area can be reduced by either using the tubes of higher temperature tolerance, or using the heat transfer fluid of higher heat removal capability. Heat transfer fluid includes water/steam, synthetic oils, liquid sodium and molten salts, among which molten salts and liquid sodium have much higher heat removal capability than steam and synthetic oils [60]. An example of a cavity receiver design is shown in Fig. 6 (b). The flux from the heliostat field is reflected through an aperture (about one third to one half of the internal absorbing surface area [60]) onto the absorbing surfaces which form the walls of the cavity. The aperture size is minimised to reduce convection and radiation losses without blocking out too much of the solar flux arriving at the receiver.

The primary limitation on receiver design is the heat flux that can be absorbed through the receiver surface and transferred into the heat transfer fluid, without overheating the receiver walls and the heat transfer fluid within them. A survey of typical design peak values is given in Table 1 [60]. The average flux over the entire absorber wall is typically one half to one third of these peak values. Two other important considerations when designing heat flux are (1) limiting the temperature gradients along the receiver panels and (2) the daily heat cycling of the receiver tubes.

\subsubsection{Parabolic dish collectors}

Parabolic dish collectors [61] use an array of parabolic dish-shaped mirrors (similar in shape to a satellite dish) to focus solar energy onto a receiver located at the common focal point of the dish mirrors. Heat transfer fluid contained in the receiver is then heated up to 
desirable working temperatures and pressures in order to generate electricity in a small engine attached to the receiver [62]. Engines currently under consideration include Stirling [63] and Brayton engines [64]. Several prototype dish-engine systems, ranging from $7 \mathrm{~kW}$ to $25 \mathrm{~kW}$ have been deployed in various locations in the USA. Parabolic dishengine systems have following advantages: high optical efficiency, low start-up losses and good modularity which can be easily scaled up to meet the power needs in remote area, where centralised power supply is too expensive.

Such parabolic dish-engine technologies have been successfully demonstrated in a number of applications, typical of which was the STEP (The Solar Total Energy Project) project in USA [65]. The STEP was a large solar parabolic dish system that operated between 1982 and 1989 in Shenandoah, Georgia, consisting of 114 dishes (each one being $7 \mathrm{~m}$ in diameter). The system produced high-pressure steam for electricity generation, medium-pressure steam for knitwear pressing, and low-pressure steam to run the air conditioning system for a knitwear factory nearby.

\subsubsection{Parabolic trough collectors}

Parabolic trough collectors can concentrate sunlight with a concentration rate of around 40, depending on the trough size. The focal line temperature can be as high as $350^{\circ} \mathrm{C}$ to $400^{\circ} \mathrm{C}$. The key component of such collectors is a set of parabolic mirrors, each of which has the capability to reflect the sunlight that is parallel to its symmetrical axis to its common focal line. At the focal line, a black metal receiver (covered by a glass tube to reduce heat loss) is placed to absorb collected heat.

Parabolic trough collectors can be orientated either in an east-west direction, tracking the sun from north to south, or a north-south direction, tracking the sun from east to west. An experimental study was performed by Bakos [66] to investigate the effect of the twoaxis tracking of parabolic trough on the sunlight collected, and they made a comparison with the case which used a fixed surface orientation (tilted at $40^{\circ}$ towards south). Their results indicated that the measured collected solar energy on the tracking surface was significantly larger (up to 46.46\%) compared with the fixed surface. Abdallah [67] experimentally examined the effect of using different types of sun tracking systems on the voltage-current characteristics and electrical power for flat-plate photovoltaics (FPPV), by comparing four types of electromechanical sun-tracking systems: two axes, one axis vertical, one axis east-west, and one axis north-south. His results indicated that the volt-ampere characteristics on the tracking surfaces were significantly greater than that on a fixed surface, with the increased electrical power gain up to $43.87 \%, 37.53 \%$, 
$34.43 \%$ and $15.69 \%$ for the four types. In addition, Kacira et al. [68] found that the optimum tilt angle varied from $13^{\circ}$ in summer to $61^{\circ}$ in winter (experiment location: latitude $37^{\circ} \mathrm{N}$ and longitude $38^{\circ} \mathrm{E}$ ). Mondol et al. [69] found that the monthly optimum collection angle for a south-facing surface varied from $20^{\circ}$ in summer to $60^{\circ}$ in winter (location: latitude $55^{\circ} \mathrm{N}$ and longitude $6^{\circ} \mathrm{W}$ ).

Parabolic trough collectors have multiple distinctive features and advantages over other types of solar systems. Firstly, they are scalable, in that their trough mirror elements can be installed along the common focal line. Secondly, they only need two-dimensional tracking (dish-engine collectors need three-dimensional tracking, making systems more complicated), so they can achieve higher tracking accuracy than dish-engine collectors.

\section{Solar thermal energy storage}

After the thermal energy is collected by solar collectors, it needs to be efficiently stored when later needed for a release. Thus, it becomes of great importance to design an efficient energy storage system. Section 3 of the present paper focuses on the solar thermal energy storage, discussing its design criteria, desirable materials and emerging technologies for heat transfer enhancement.

\subsection{Criteria for design}

There are three main aspects that need to be considered in the design of a solar thermal energy storage system: technical properties, cost effectiveness and environmental impact.

Excellent technical properties are the key factors to ensure the technical feasibility of a solar thermal energy storage system. Firstly, a high thermal storage capacity (sensible heat, latent heat or chemical energy) is essential to reduce the system volume and increase the system efficiency. Secondly, a good heat transfer rate must be maintained between the heat storage material and heat transfer fluid, to ensure that thermal energy can be released/absorbed at the required speed. Thirdly, the storage material needs to have good stability to avoid chemical and mechanical degradation after a certain number of thermal cycles. The other technical properties, such as compatibility and heat loss, are listed in Table 2.

Cost effectiveness determines the payoff period of the investment, and therefore is very important. The cost of a solar thermal energy storage system mainly consists of three parts [11]: storage material, heat exchanger and land cost. Cost effectiveness is usually connected with the aforementioned technical properties, because high thermal 
storage capacity and excellent heat transfer performance can significantly reduce the system volume.

Apart from technical properties and cost effectiveness, there are other criteria to be considered, such as operation strategy and integration to a specific power plant, which are listed in Table 2.

\subsection{Materials}

The materials used for solar thermal energy storage are classified into three main categories according to different storage mechanisms: sensible heat storage, latent heat storage and chemical heat storage (with their storage capacity in ascending order). Sensible heat storage is the most developed technology and there are a large number of low-cost materials available [70-72], but it has the lowest storage capacity which significantly increases the system size. Latent heat storage has much higher storage capacity, but poor heat transfer usually accompanies if not employing heat transfer enhancement. Chemical storage has the highest storage capacity, but the following problems restrict its application: complicated reactors needed for specific chemical reactions, weak long-term durability (reversibility) and chemical stability.

\subsubsection{Sensible heat storage materials}

In sensible heat storage, thermal energy is stored during the rising or dropping of temperatures of thermal storage media, which can be either solid state or liquid state. Table 3 shows the main characteristics of the most commonly-used solid-state thermal storage materials [11], including sand-rock minerals, concrete, fire bricks and ferroalloy materials. These materials have working temperatures from $200{ }^{\circ} \mathrm{C}$ to $1200{ }^{\circ} \mathrm{C}$, and have excellent thermal conductivities: $1.0 \mathrm{~W} /(\mathrm{m} \mathrm{K})-7.0 \mathrm{~W} /(\mathrm{m} \mathrm{K})$ for sand-rock minerals, concrete and fire bricks, $37.0 \mathrm{~W} /(\mathrm{m} \mathrm{K})-40.0 \mathrm{~W} /(\mathrm{m} \mathrm{K})$ for ferroalloy materials. The materials shown in Table 3 are all low-cost, ranging from $0.05 \mathrm{US} \$ / \mathrm{kg}-5.00 \mathrm{US} \$ / \mathrm{kg}$. The only disadvantage is their heat capacities being rather low, ranging from $0.56 \mathrm{~kJ} /(\mathrm{kg}$ $\left.{ }^{\circ} \mathrm{C}\right)$ to $1.3 \mathrm{~kJ} /\left(\mathrm{kg}^{\circ} \mathrm{C}\right)$, which can make the storage unit unrealistically large.

Liquid-state thermal energy storage materials are shown in Table 4 [11], including oils, liquid sodium and inorganic molten salts. Oils have rather high vapour pressure [71] which causes serious safety issues due to requiring an airtight system. Liquid sodium has a thermal conductivity as high as $71.0 \mathrm{~W} /(\mathrm{m} \mathrm{K})$; however, it is highly unstable in chemical reactivity, therefore incurring much more cost by adopting extra safety measures. Molten salts are regarded as the ideal materials for use in solar power plant 
[70-72, 11] because of their excellent thermal stability under high temperatures, low vapour pressure, low viscosity, high thermal conductivities, non-flammability and nontoxicity. Zhao and $\mathrm{Wu}[71]$ reported a serial of novel ternary salt mixtures with ultra-low melting temperatures of $76^{\circ} \mathrm{C}, 78{ }^{\circ} \mathrm{C}$ and $80{ }^{\circ} \mathrm{C}$, which are all below $100{ }^{\circ} \mathrm{C}$ so that the system unfreezing becomes much easier. Their salt mixtures consisting of $\mathrm{KNO}_{3}, \mathrm{LiNO}_{3}$ and $\mathrm{Ca}\left(\mathrm{NO}_{3}\right)_{2}$ showed much lower viscosities (more than $80 \%$ ) than synthetic oils and commercial molten salts. Their salt mixtures were also found to have good chemical stability under high temperatures $\left(500{ }^{\circ} \mathrm{C}\right)$. Such eutectic salts with melting temperatures below $100{ }^{\circ} \mathrm{C}$ were also reported by Wang et al. [73] recently. They found a novel quaternary eutectic salt with its melting temperature as low as $99{ }^{\circ} \mathrm{C}$.

The common advantage of sensible heat storage is its low cost, ranging from 0.05 US $\$ / \mathrm{kg}$ to $5.00 \mathrm{US} \$ / \mathrm{kg}$, compared to the high cost of latent heat storage which usually ranges from $4.28 \mathrm{US} \$ / \mathrm{kg}$ to $334.00 \mathrm{US} \$ / \mathrm{kg}[70]$.

\subsubsection{Latent heat storage materials}

Phase change materials (PCMs) can store/release a large amount of heat when reforming their phase structures during melting/solidification or gasification/liquefaction processes. Since the phase-transition enthalpy of PCMs are usually much higher (100-200 times, shown in Table 5) than sensible heat, latent heat storage has much higher storage density than sensible heat storage. Table 5 lists the thermal-physical properties of several commercial PCMs, inorganic salts and eutectics $[11,70]$. These materials listed in Table 5 have phase change temperatures ranging form 100 to $897{ }^{\circ} \mathrm{C}$, and latent heat ranging from 124 to $560 \mathrm{~kJ} / \mathrm{kg}$.

Unlike sensible heat storage in which materials have a large temperature rise/drop when storing/releasing thermal energy, latent heat storage can work in a nearly isothermal way, due to the phase change mechanism. This makes latent heat storage favourable for those applications which require strict working temperatures. However, the main disadvantage of latent heat storage is its low thermal conductivities, which mostly fall into the range of $0.2 \mathrm{~W} /(\mathrm{m} \mathrm{K})$ to $0.7 \mathrm{~W} /(\mathrm{m} \mathrm{K})$, and therefore relative heat transfer enhancement technologies must be adopted [28].

\subsubsection{Chemical heat storage materials}

Special chemicals can absorb/release a large amount of thermal energy when they break/form certain chemical bonds during endothermal/exothermal reactions. Based on such characteristics, the storage method making use of chemical heat has been invented. Suitable materials for chemical heat storage can be organic or inorganic, as long as their 
reversible chemical reactions involve absorbing/releasing a large amount of heat. When designing a chemical storage system, three basic criteria need to be considered: excellent chemical reversibility, large chemical enthalpy change and simple reaction conditions (reactions cannot be too complicated to be realised).

Table 6 gives a list of potential materials for chemical heat storage, most of which have an enthalpy change of $3.6 \mathrm{GJ} / \mathrm{m}^{3}-4.4 \mathrm{GJ} / \mathrm{m}^{3}$. As seen from Table 5 and Table 6 , latent heat storage has storage densities in the order of $\mathrm{MJ} / \mathrm{m}^{3}$, whilst chemical heat storage has much higher storage densities in the order of $\mathrm{GJ} / \mathrm{m}^{3}$.

However, chemical storage has not yet been extensively researched, and its application is limited due to the following problems: complicated reactors needed for specific chemical reactions, weak long-term durability (reversibility) and chemical stability.

\subsection{Heat transfer enhancement technologies}

\subsubsection{Incorporation of high-thermal conductivity enhancers}

Latent heat storage, providing a high heat storage density with a small PCM volume and a relatively small temperature variation, has gained increasing attention in the past ten years. However, most PCMs suffer from the common problem of inherently low thermal conductivities [27, 28], which significantly increase the charging and discharging time for thermal energy storage, often making the system response time too long to meet the requirements. The system response time for charging and discharging is a key factor when designing a solar thermal energy storage system, and if it does not reach the required value, serious safety issues may emerge.

To enhance heat transfer in thermal energy storage systems, the insertion of highthermal conductivity materials has been tested; these include metal fins, metal beads and metal powders. By incorporating these metal insertions with high thermal conductivities, the heat transfer is improved $[80,81]$. However, the enhancement effects seem to be very limited; the increase is usually in the range from $60 \%$ to $150 \%$. Carbon materials [82-84] can have thermal conductivities as high as $470 \mathrm{~W} /(\mathrm{m} \mathrm{K})$, so they have also been examined for heat transfer enhancement in thermal energy storage systems. Nakaso et al. [83] tested the use of carbon fibres to enhance heat transfer in thermal storage tanks, reporting a twofold rise in effective thermal conductivities. Their carbon cloths and carbon brushes (both made of high-thermal conductivity carbon fibres) are shown in Fig. 7. They also found that the carbon cloths had better thermal performance than carbon brushes because the cloth structure was more continuous than the brush structure. Fukai 
et al. [85] investigated how different spatial arrangements of carbon fibres affected heat transfer. They set up two different arrangements: one using randomly oriented fibres and the other using fibre brushes with carbon fibres oriented in a specific direction. Figure 8 gives a comparison between the two types, showing that the effective thermal conductivity of the brush type (directional arrangement) is around twice higher than that of the random-oriented arrangement. They reported that the fibre length only has a minor effect on increasing effective thermal conductivity.

The volume percentage of carbon fibres in [83] was only around $1 \%$, so the thermal conductivity can be further increased by incorporating more carbon materials. Paraffin/CENG composites can have a carbon percentage as much as 5\% (CENG means compressed expanded natural graphite), and are usually made by impregnating paraffin (with the aid of capillary forces) into a porous graphite matrix to form a stable composite material. Such composites were elaborated and characterised by Py et al. [82]; they have good thermal conductivities, but they present the anisotropy in axial and radial directions, which makes the heat transfer performance vary in different directions. To avoid anisotropy, Paraffin/EG (Expanded Graphite) composites were introduced, and they can be made to incorporate even more carbon. Sari and Karaipekli [86] made and compared two samples, the first made from pure paraffin, and the second a Paraffin/EG (Expanded Graphite) composite, which are shown in Fig. 9. They found that the Paraffin/EG composite with mass fraction of $2 \%, 4 \%, 7 \%$, and $10 \% \mathrm{EG}$ increased effective thermal conductivities by $81.2 \%, 136.3 \%, 209.1 \%$ and $272.7 \%$, respectively. However, the main disadvantage of EG is its structural discontinuity, which means that heat cannot be transferred very smoothly and efficiently.

To overcome the disadvantages of CENG (anisotropy) and EG (structural discontinuity), metal foams (shown in Fig. 10) were recently introduced. Metal foams have ultra-light isotropic structures (porosity ranging from $85 \%$ to $97 \%$ ), continuous metal matrices, and relatively high thermal conductivity. Because of all these excellent physical characteristics, metal foams are considered to be a promising solution to the heat transfer enhancement of PCMs. Zhou and Zhao [87, 88] investigated heat transfer enhancement for PCMs by using expanded graphite and metal foams. They found that both of these increased heat transfer rate significantly, but metal foams showed better performance than expanded graphite, which is shown in Fig. 11. The reason is that the structures inside the expanded graphite are sparse, whilst metal foams have much more continuous matrix than expanded graphite, which means heat can be easily transferred to PCMs. Tian and Zhao [27] analysed how different metal foams affect heat transfer in 
PCMs. Their investigation was based on the two-equation non-equilibrium heat transfer model, and the coupled problem of heat conduction and natural convection was solved for phase change heat transfer in metal foams. Their results showed that heat can be quickly transferred through the metal foam solid structure to the whole domain of PCMs. However, at the two-phase zone and liquid zone, metal foams were found to have large flow resistance, thus suppressing the natural convection in PCMs. Nonetheless, the overall heat transfer performance of the PCM-metal foam sample was still superior to that of the pure PCM samples, which implies that the enhancement of heat conduction offsets or exceeds the natural convection loss.

\subsubsection{Cascaded storage}

The main advantage of latent heat storage over sensible heat storage is the high storage density within a small temperature band. Figure 12(a) [89] gives a comparison between a sensible heat storage system and a latent heat storage system made of a single PCM. For the small temperature difference covering the phase change, there is a factor of three between the heat stored in the latent heat storage system and the sensible heat storage system. For a larger temperature difference, the advantage of the latent heat storage shrinks to $6: 4=1.5$, so that there is no reason to prefer a latent heat storage system to a sensible heat storage system.

Mehling and Cabeza [89] suggested that the use of a cascaded arrangement of multiple PCMs with different melting temperatures should solve the above problem. Figure 12(b) [89] shows a typical three-stage cascaded storage system: the PCM I with the lowest melting temperature is heated from $\mathrm{T}_{1}$ to $\mathrm{T}_{2}$, the PCM II with the medium melting temperature is heated from $\mathrm{T}_{2}$ to $\mathrm{T}_{3}$, and the PCM III with the highest melting temperature is heated from $T_{3}$ to the maximum temperature. Using such a cascaded storage system, the difference of the stored energy between cascaded latent heat storage and single sensible heat storage is $10: 4=2.5$.

Another reason for using cascaded thermal energy storage is illustrated as following. A very common practical situation is that the charging and discharging time is usually limited and the heat needs to be absorbed or released quickly. When charging a storage system with only a single-stage PCM, the heat transfer fluid rapidly transfers heat to the PCM. The temperature of the heat transfer fluid therefore reduces, which reduces the temperature difference between the PCM and heat transfer fluid [89] and leads to poor heat transfer at the end of the storage. As a result, the PCM is melted rapidly at the entrance part where the heat transfer fluid enters the storage, but the PCM is melted more 
slowly at the end of the storage where the heat transfer fluid outflows. For the discharging process, the problem is that the PCM at the end of the storage might not be used for latent heat storage as the temperature of heat transfer fluid rises. By using cascaded thermal energy storage, such problems can be all solved. Figure 13 gives a comparison between a single-stage PCM system and a five-stage cascaded PCM system $[70,59]$. For charging process, a PCM with a lower melting temperature can be placed at the end of the heat exchanger, so that the temperature difference can be large enough to ensure all PCMs to be melted. The cascaded storage system also works efficiently for discharging process. Michels and Pitz-Paal [90] investigated cascaded latent heat storage for parabolic trough solar power plants, and they found that a higher portion of the PCM can run through the phase change process and a more uniform heat transfer fluid outlet temperature was achieved during the discharging process than in the traditional singlestage storage system.

As the research by Michels and Pitz-Paal [90] suggested, Cascaded Thermal Energy Storage (CTES) was found to have higher energy utilisation efficiency than the traditional Single-stage Thermal Energy Storage (STES). Very recently, Tian and Zhao [91] examined and compared STES, CTES and their newly-proposed Metal Foam-enhanced Cascaded Thermal Energy Storage (MF-CTES). Their research showed that the CTES can not only achieve higher energy efficiency (up to 30\%) than STES but can also achieve higher exergy efficiency (up to 23\%) than STES. Other findings from their research are: Firstly, MF-CTES can further increase heat transfer rate of CTES by 2-7 times, depending on the properties of the metal-foam samples used (higher pore density and lower porosity can achieve a better performance). Secondly, MF-CTES cannot improve exergy efficiency of CTES, but can help CTES to finish melting more quickly by having higher heat transfer rates (melting time reduced by 67-87\%). Thirdly, exergy transfer rate of CTES is further increased by 2-7 times if MF-CTES is used.

\section{An overview of existing and future solar power stations}

\subsection{Existing solar power stations}

Spain has the most solar thermal power installations in the World, with the U.S. ranked the second. As shown in Table 7, most of existing solar power stations (71.0\%) use parabolic troughs to harvest solar energy, as it is a relatively mature technology compared to other technologies discussed in Section 2.2, such as central solar towers 
(12.9\%), parabolic dishes (3.2\%) and Fresnel reflectors (12.9\%). The installed capacity for each power station ranges from $0.25 \mathrm{MW}$ to $354 \mathrm{MW}$, and the overall installed capacity amounts to $1845.65 \mathrm{MW}$. Information on heat transfer fluid and thermal energy storage used in these power stations is also provided in Table 7. Heat transfer fluids include thermal oils, water, air, molten salts and organics such as the Diphenyl/Biphenyl oxide pair. Their working temperatures range from $93{ }^{\circ} \mathrm{C}$ to $700{ }^{\circ} \mathrm{C}$. Thermal energy storage using ceramics and molten salts can be found in most power stations. The storage time ranges from 0.5 hours to 8 hours. Natural gas was widely used in the power stations without a storage unit.

Up to now, the Solar Energy Generating Systems (SEGS, $354 \mathrm{MW}$ ) in the Mojave Desert in California [133-135] have the largest power installation in the World; there are nine solar power plants and in this location, solar insolation is abundant throughout the year. The SEGS use parabolic troughs to collect solar energy (concentration ratio of $71-$ 80 times), and use synthetic oil (Therminol $\left.{ }^{\circledR}\right)$ as heat transfer fluid $\left(349{ }^{\circ} \mathrm{C}-390{ }^{\circ} \mathrm{C}\right)$ to heat the working fluid (water) that boils and drives the steam turbine used in Rankine Cycle [4]. The total average gross solar output for all nine plants is around $75 \mathrm{MW}-\mathrm{a}$ capacity factor of $21 \%$. In addition, their turbines can be utilised at night by burning natural gas. It was claimed that the SEGS can power 232,500 homes and displace 3,800 tons of pollution per year.

There are three solar power plants using ISCC (Integrated Solar Combined Cycle) technology. They are the Martin Next Generation Solar Energy Centre in the U.S.A., the Archimede Solar Power Plant in Italy and the Yazd Integrated Solar Combined Cycle Power Station in Iran. ISCC technology combines the benefits of clean solar energy with the highly efficient Combined Cycle, making the whole system more efficient and robust because thermal storage becomes not essential) [150,151].

\subsection{Solar power stations under construction}

It has been reported that several new solar thermal power stations of even greater installed capacity are under construction in a variety of locations. They are listed in Table 8 , all of which will have a capacity of more than $100 \mathrm{MW}$. It can be seen that parabolic troughs are still the mainstream technology because of its maturity; however, solar towers technology is the future because it can achieve much higher thermodynamic efficiencies than parabolic toughs due to having much higher concentration ratios, more information of which can be found in Section 2.2.1. 
A solar thermal power station must operate in a smooth and stable way (continuous electricity production at all times), so it is of great priority to develop more advanced technologies in solar collectors and thermal storage systems. However as mentioned in previous sections, most thermal storage materials have low thermal conductivities $[4,11]$ which jeopardise the charging/discharging processes for electricity production. Heat transfer enhancement for high-temperature PCMs used in solar thermal plants becomes extremely important. Recently $\mathrm{Wu}$ and Zhao [161] conducted an experimental investigation of heat transfer enhancement for high-temperature thermal storage systems by using porous materials. They observed a significant heat transfer improvement by embedding molten salts into porous metals or expanded graphite materials. For the future development of high-temperature thermal storage systems used in solar thermal power plants, two developments would appear to be particularly promising - firstly mixing enhancer materials with a PCM to form a chemically stable composite with high thermal conductivity, and secondly designing a special flow passage to enhance heat transfer during charging/discharging processes.

\section{Conclusions}

This paper has reviewed the state of the art on solar thermal applications, with the focus on the two core subsystems: solar collectors and thermal energy storage subsystems.

A variety of solar collectors have been discussed, including non-concentrating types and concentrating types. Among non-concentrating collectors, the PVT solar collectors show the best overall performance. Sun-tracking concentrating solar collectors have also been examined, in terms of optical optimisation, heat loss reduction, heat recuperation enhancement, different sun-tracking mechanisms. Three different types of concentrating solar collectors have been described and compared: heliostat field collectors, parabolic dish collectors and parabolic trough collectors.

The materials used for high-temperature thermal energy storage systems have been compared, and a comparison between different categories of thermal storage systems has been presented. Molten salts with excellent properties are considered to be the ideal materials for high-temperature thermal storage applications. Heat transfer enhancement is also essential to overcome the poor heat transfer in these applications. For this purpose, graphite composites and metal foams are found to be the ideal materials. Lastly, the current status of existing solar power stations has been reviewed, with potential future research developments being suggested. 


\section{Acknowledgements}

This work was supported by the UK Engineering and Physical Sciences Research Council (EPSRC grant number: EP/F061439/1), the University of Warwick Strategic Award (grant number: RD07110), and the National Natural Science Foundation of China (NSFC grant number: 51176110). The authors also gratefully acknowledge the valuable support by Professor Keith Richard Godfrey from University of Warwick in United Kingdom.

\section{References}

[1] Smil V. General Energetics: Energy in the Biosphere and Civilization. $1^{\text {st }}$ ed. New York: John Wiley \& Sons; 1991.

[2] The Earth's energy budget http://www.nasa.gov/images/content/57911main_Earth_Energy_Budget.jpg [Accessed 16.11.2012].

[3] De Winter F. Solar collectors, energy storage, and materials. Massachusetts: The MIT press; 1991.

[4] Zalba B, Marin JM, Cabeza LF, Mehling H. Review on thermal energy storage with phase change: materials, heat transfer analysis and applications. Appl. Therm. Eng. 2003;23:251-283.

[5] Sharma A, Tyagi VV, Chen CR, Buddhi D. Review on thermal energy storage with phase change materials and applications. Renew. Sust. Energ. Rev. 2009;13:318-345.

[6] Kalogirou SA. Solar thermal collectors and applications. Prog. Energ. Combust. 2004;30:231-295.

[7] Farid MM, Khudhair AM, Razack SAK, Al-Hallaj S. A review on phase change energy storage: materials and applications. Energ. Convers. Manage. 2004;45:15971615 .

[8] Kenisarin M, Mahkamov K. Solar energy storage using phase change materials. Renew. Sust. Energ. Rev. 2007;11:1913-1965.

[9] Oró, E, de Gracia A, Castell A, Farid MM, Cabeza LF. Review on phase change materials (PCMs) for cold thermal energy storage applications. Appl. Energ. 2012; In Press, Corrected Proof.

[10] Kenisarin M. High-temperature phase change materials for thermal energy storage. Renew. Sust. Energ. Rev. 2010;14:955-970.

[11] Gil A, Medrano M, Martorell I, Lázaro A, Dolado P, Zalba B, Cabeza LF. State of the art on high temperature thermal energy storage for power generation. Part 1concepts, materials and modellization. Renew. Sust. Energ. Rev. 2010;14:31-55.

[12] Khoukhi M, Maruyama S. Theoretical approach of a flat plate solar collector with clear and low-iron glass covers taking into account the spectral absorption and emission within glass covers layer. Renew. Energ. 2005;30:1177-1194.

[13] Parsons RA. ASHRAE Handbook: Heating, Ventilating, and Air-Conditioning Applications. In: Chapter 30. Atlanta: ASHRAE; 1995. 
[14] Hellstrom B, Adsten M, Nostell P, Karlsson B, Wackelgard E. The impact of optical and thermal properties on the performance of flat plate solar collectors. Renew. Energ. 2003;28:331-344.

[15] Tripanagnostopolous Y, Souliotis M, Nousia T. Solar collectors with colored absorbers. Sol. Energy 2000;68:343-356.

[16] Wazwaz J, Salmi H, Hallak R. Solar thermal performance of a nickel-pigmented aluminium oxide selective absorber. Renew. Energ. 2002;27:277-292.

[17] Orel ZC, Gunde MK, Hutchins MG. Spectrally selective solar absorbers in different non-black colours. In: Proceedings of WREC VII (CD-ROM); Cologne, Germany, 2002.

[18] Konttinen P, Lund PD, Kilpi RJ. Mechanically manufactured selective solar absorber surfaces. Sol. Energ. Mat. Sol. C. 2003;79:273-283.

[19] Francia G. A new collector of solar radiant energy. In: Proceedings of the United Nations Conference on New Sources of Energy, p. 572; paper No. F6; Rome, Italy, 1961.

[20] Slaman M, Griessen R. Solar collector overheating protection. Sol. Energy 2009;83:982-987.

[21] Kumar KR, Reddy KS. Thermal analysis of solar parabolic trough with porous disc receiver. Appl. Energ. 2009;86:1804-1812.

[22] Lambert AA, Cuevasa S, del Río JA. Enhanced heat transfer using oscillatory flows in solar collectors. Sol. Energy 2006;80:1296-1302.

[23] Ho CD, Yeh HM, Wang RC. Heat-transfer enhancement in double-pass flat-plate solar air heaters with recycle. Energy 2005;30:2796-2817.

[24] Ackermann JA, Ong LE, Lau SC. Conjugate heat transfer in solar collector panels with internal longitudinal corrugated fins - Part I: Overall results. Forschung Im Ingenieurwesen 1995;61:84-92.

[25] Sopian K, Alghoula MA, Alfegib EM, Sulaimana MY, Musab EA. Evaluation of thermal efficiency of double-pass solar collector with porous-nonporous media. Renew. Energ. 2009;34:640-645.

[26] Martinopoulos G, Missirlis D, Tsilingiridis G, Yakinthos K, Kyriakis N. CFD modeling of a polymer solar collector. Renew. Energ. 2010;35:1499-1508.

[27] Tian Y, Zhao CY. A numerical investigation of heat transfer in phase change materials (PCMs) embedded in porous metals. Energy 2011;36:5539-5546.

[28] Zhao CY, Lu W, Tian Y. Heat transfer enhancement for thermal energy storage using metal foams embedded within phase change materials (PCMs). Sol. Energy 2010;84:1402-1412.

[29] Tian Y, Zhao CY. Heat transfer analysis for phase change materials (PCMs). In: Proceedings of the $11^{\text {th }}$ International Conference on Energy Storage (Effstock 2009); Stockholm, Sweden, 2009.

[30] Saha SK, Mahanta DK. Thermodynamic optimization of solar flat-plate collector. Renew. Energ. 2001;23:181-193. 
[31] Farahat S, Sarhaddi F, Ajam H. Exergetic optimization of flat plate solar collectors. Renew. Energ. 2009;34:1169-1174.

[32] Selmi M, Al-Khawaja MJ, Marafia A. Validation of CFD simulation for flat plate solar energy collector. Renew. Energ. 2008;33:383-387.

[33] Aste N, Chiesa G, Verri F. Design, development and performance monitoring of a photovoltaic-thermal (PVT) air collector. Renew. Energ. 2008;33:914-927.

[34] Wang RZ, Zhai XQ. Development of solar thermal technologies in China. Energy 2012;35:4407-4416.

[35] Bergene T, Lovvik OM. Model calculations on a flat-plate solar heat collector with integrated solar cells. Sol. Energy 1995;55:453-462.

[36] Kalogirou SA. Use of TRNSYS for modelling and simulation of a hybrid PVthermal solar system for Cyprus. Renew. Energ. 2001;23:247-260.

[37] Prakash J. Transient analysis of a photovoltaic thermal solar collector for cogeneration of electricity and hot air water. Energ. Convers. Manage. 1994;35:967-972.

[38] Agarwal RK, Garg HP. Study of a photovoltaic thermal system--thermosyphonic solar water heater combined with solar cells. Energ. Convers. Manage. 1994;35:605620.

[39] Fujisawa T, Tani T. Optimum design for residential photovoltaic-thermal binary utilization system by minimizing auxiliary energy. Electrical Engineering in Japan (English translation of Denki Gakkai Ronbunshi) 2001;137:28-35.

[40] Anonymous authors: New generation of Hybrid Solar PV/T collectors, prepared by LESO-PB/EPFL, Enecolo AG and Ernst Schweizer AG for the Swiss Federal Office of Energy 2000:1-55.

[41] Platz R, Fischer D, Zufferey MA, Anna Selvan JA, Haller A, Shah A. Hybrid collectors using thin-film technology. In: Proceedings of the $26^{\text {th }}$ Photovoltaics Specialists Conference (IEEE), p. 1293-1296; Anaheim, CA, USA, 1997.

[42] Tonui JK, Tripanagnostopoulos Y. Improved PV/T solar collectors with heat extraction by forced or natural air circulation. Renew. Energ. 2007;32:623-637.

[43] Hegazy AA. Comparative study of the performances of four photovoltaic/thermal solar air collectors. Energ. Convers. Manage. 2000;41:861-881.

[44] Othman MY, Yatim B, Sopian K, Abu Bakar MN. Performance analysis of a double-pass photovoltaic/thermal (PV/T) solar collector with CPC and fins. Renew. Energ. 2005;30:2005-2017.

[45] Garg HP, Adhikari RS. Conventional hybrid photovoltaic/thermal (PV/T) air heating collectors: steady-state simulation. Renew. Energ. 1997;11:363-385.

[46] Brogren M, Nostell P, Karlsson B. Optical efficiency of a PV-thermal hybrid CPC module. In: Proceedings of the Eurosun 2000-ISES Europe Solar Conference; Copenhagen, 2000.

[47] Brogren M. Low-concentrating photovoltaic systems with parabolic reflectors. Licentiate Thesis, Division of Solid State Physics, Uppsala University, 2001.

[46] Fujisawa T, Tani T. Annual exergy evaluation on photovoltaic-thermal hybrid collector. Sol. Energ. Mat. Sol. C. 1997;47:135-148. 
[49] Huang BJ, Lin TH, Hung WC, Sun FS. Performance evaluation of solar photovoltaic/thermal systems. Sol. Energy 2001;70:443-448.

[50] Coventry J. Simulation of a concentrating PV/thermal collector using TRNSYS. In: Proceedings of the ANZSES Solar Energy Conference; Newcastle, UK, 2002.

[51] Zondag HA, De Vries DW, Van Helden WGJ, Van Zolingen RJC, Van Steenhoven AA. The thermal and electrical yield of a PV-thermal collector. Sol. Energy 2002;72:113-128.

[52] Joshi AS, Tiwari A. Energy and exergy efficiencies of a hybrid photovoltaicthermal (PV/T) air collector. Renew. Energ. 2007;32:2223-2241.

[53] Tina GM, Rosa-Clot M, Rosa-Clot P, Scandura PF. Optical and thermal behavior of submerged photovoltaic solar panel: SP2. Energy 2012;39:17-26.

[54] Palmer KF, Williams D. Optical properties of water in the near infrared. J. Opt. Soc. Am. 1974;64:1107-1110.

[55] Robles-Ocampo B, Ruíz-Vasquez E, Canseco-Sánchezb H, Cornejo-Mezac RC, Trápaga-Martínezd G, García-Rodrigueza FJ, González-Hernándeze J, Vorobiev YV. Photovoltaic/thermal solar hybrid system with bifacial PV module and transparent plane collector. Sol. Energ. Mat. Sol. C. 2007;91:1966-1971.

[56] Nelson J. The physics of solar cells. London: Imperial College Press; 2003.

[57] Pei G, Fu H, Zhu H, Ji J. Performance study and parametric analysis of a novel heat pipe PV/T system. Energy 2012;37:384 - 395.

[58] Wei XD, Lu ZW, Wang ZF, Yu WX, Zhang HX, Yao ZH. A new method for the design of the heliostat field layout for solar tower power plant. Renew. Energ. 2010;35:1970-1975.

[59] Medrano M, Gil A, Martorell I, Potou X, Cabeza LF. State of the art on hightemperature thermal energy storage for power generation. Part 2-Case studies. Renew. Sust. Energ. Rev. 2010;14:56-72.

[60] Battleson KW. Solar power tower design guide: solar thermal central receiver power systems, Sandia National Labs Report SAND81-8005, 1981

[61] Parabolic dish collector. http://www.geni.org/globalenergy/library/articlesrenewable-energy-transmission/solar.shtml

[Accessed 16.11.2012].

[62] Stirling engine attached to parabolic dish collector.

http://www.ejsong.com/mdme/memmods/MEM23041A/thermo/heat_engines_files/Sol ar Stirling.html

[Accessed 16.11.2012].

[63] Tavakolpour AR, Zomorodian A, Golneshan AA. Simulation, construction and testing of a two-cylinder solar Stirling engine powered by a flat-plate solar collector without regenerator. Renew. Energ. $2008 ; 33: 77-87$.

[64] Zhang Y, Lin B, Chen J. Optimum performance characteristics of an irreversible solar-driven Brayton heat engine at the maximum overall efficiency. Renew. Energ. 2007;32:856-867.

[65] http://www.osti.gov/energycitations/product.biblio.jsp?osti id=5155159

[Accessed 16.11.2012]. 
[66] Bakos GC. Design and construction of a two-axis Sun tracking system for parabolic trough collector (PTC) efficiency improvement. Renew. Energ. 2006;31:2411-2421.

[67] Abdallah S. The effect of using sun tracking systems on the voltage-current characteristics and power generation of flat plate photovoltaics. Energ. Convers. Manage. 2004;45:1671-1679.

[68] Kacira M, Simsek M, Babur Y, Demirkol S. Determining optimum tilt angles and orientations of photovoltaic panels in Sanliurfa, Turkey. Renew Energy 2004;29:12651275

[69] Mondol JD, Yohanis YG, Norton B. The impact of array inclination and orientation on the performance of a grid-connected photovoltaic system. Renew. Energ. 2007;32:118-140.

[70] Pilkington Solar International GmbH. Survey of thermal storage for parabolic trough power plants. NREL Report, NREL/SR-550-27925; 2000.

[71] Zhao CY, Wu ZG. Thermal property characterization of a low melting-temperature ternary nitrate salt mixture for thermal energy storage systems. Sol. Energ. Mat. Sol. C. 2011;95:3341-3346.

[72] Zhao CY, Zhou D, Wu ZG. Hear transfer enhancement of phase change materials (PCMs) in low and high temperature thermal storage by using porous materials. In: Proceedings of the $14^{\text {th }}$ International Heat Transfer Conference (IHTC-14); Washington DC, USA, 2010.

[73] Wang T, Mantha D, Reddy RG. Novel low melting point quaternary eutectic system for solar thermal energy storage. Appl. Energ. 2012; correct proof, in press.

[74] Shiizaki S, Nagashimga I, Iwata K, Hosoda T, Kameyama H. Development of plate fin reactor for heat recovery system using methanol decomposition. In: Proceedings of the $8^{\text {th }}$ International Conference on Thermal Energy Storage (Terrastock 2000); Stuttgart, Germany, 2000.

[75] Hahne E. Thermal energy storage some view on some problems. In: Proceedings of the $8^{\text {th }}$ International Heat Transfer Conference San Francisco; USA, 1986.

[76] Lovegrove K. A solar driven ammonia based thermochemical energy storage system. In: Proceedings of ISES'99 Solar world congress Jerusalem; Israel, 1999.

[77] Kubota M, Yokoyama K, Watanabe F, Hasatani M. Heat releasing characteristics of $\mathrm{CaO} / \mathrm{CaCO}_{3}$ reaction in a packed bed for high temperature heat storage and temperature up-grading. In: Proceedings of the $8^{\text {th }}$ International Conference on Thermal Energy Storage (Terrastock 2000); Stuttgart, Germany, 2000.

[78] Steinfeld A, Sanders S, Palumbo R. Design aspects of solar thermochemical engineering - a case study: two-step water splitting cycle using $\mathrm{Fe}_{3} \mathrm{O}_{4} / \mathrm{FeO}$ re-dox system. Sol. Energy 1999;65:43-53.

[79] Murray JP. Solar production of aluminium ore by direct reduction of ore to Al-Si alloy. In: Proceedings of ISES'99 Solar World Congress; Jerusalem, Israel, 1999.

[80] Mettawee ES, Assassa GMR. Thermal conductivity enhancement in a Latent Heat Storage System. Sol. Energy 2007;81:839-845.

[81] Stritih U. An experimental study of enhanced heat transfer in rectangular PCM thermal storage. Int. J. Heat Mass Tran. 2004;47:2841-2847. 
[82] Py X, Olives R, Mauran S. Paraffin/porous-graphite-matrix composite as a high and constant power thermal storage material. Int. J. Heat Mass Tran. 2001;44:27272737.

[83] Nakaso K, Teshima H, Yoshimura A, Nogami S, Hamada S, Fukai J. Extension of heat transfer area using carbon fiber cloths in latent heat thermal energy storage tanks. Chem. Eng. Process: Process Intensif. 2008;47:879-885.

[84] Lafdi K, Mesalhy O, Elyafy A. Graphite foams infiltrated with phase change materials as alternative materials for space and terrestrial thermal energy storage applications. Carbon 2008;46:159-168.

[85] Fukai J, Kanou M, Kodama Y, Miyatake O. Thermal conductivity enhancement of energy storage media using carbon fibers. Energ. Convers. Manage. 2000;41:15431556.

[86] Sar1 A, Karaipekli A. Thermal conductivity and latent heat thermal energy storage characteristics of paraffin/expanded graphite composite as phase change material. Appl. Therm. Eng. 2007;27:1271-1277.

[87] Zhou D, Zhao CY. Experimental Investigations on Heat Transfer in Phase Change Materials (PCMs) Embedded with Porous Materials. Appl. Therm. Eng. 2011;31:970977.

[88] Zhou D, Zhao CY. Solid/liquid phase change heat transfer in latent teat thermal energy storage. In: Proceedings of the $3^{\text {rd }}$ ASME International Conference on Energy Sustainability; San Francisco, California, USA, July 2009.

[89] Mehling H, Cabeza LF. Heat and cold storage with PCM: Chapter 6 - Integration of active storages into systems, p. 191-189; Berlin: Springer Publication Corporation, 2008.

[90] Michelsa H, Pitz-Paal R. Cascaded latent heat storage for parabolic trough solar power plants. Sol. Energy 2007;81:829-837.

[91] Tian Y, Zhao CY. A thermal and exergetic analysis of Metal Foam-enhanced Cascaded thermal Energy storage (MF-CTES). Int. J. Heat Mass Tran. 2013;58:86-96.

[92] Solnova solar power station.

http://en.wikipedia.org/wiki/Solnova_Solar_Power_Station

[Accessed 16.11.2012].

[93] Solnova 1. http://www.nrel.gov/csp/solarpaces/project detail.cfm/projectID=21

[Accessed 16.11.2012]

[94] Solnova 3. http://www.nrel.gov/csp/solarpaces/project detail.cfm/projectID=22 [Accessed 16.11.2012]

[95] Solnova 4. http://www.nrel.gov/csp/solarpaces/project detail.cfm/projectID=25 [Accessed 16.11.2012].

[96] Andasol Solar Power Station.

http://en.wikipedia.org/wiki/Andasol_Solar_Power_Station

[Accessed 16.11.2012].

[97] Andasol-1. http://www.nrel.gov/csp/solarpaces/project_detail.cfm/projectID=3

[Accessed 16.11.2012]. 
[98] Andasol-2. http://www.nrel.gov/csp/solarpaces/project_detail.cfm/projectID=4 [Accessed 16.11.2012].

[99] Andasol-3. http://www.nrel.gov/csp/solarpaces/project_detail.cfm/projectID=4117 [Accessed 16.11.2012].

[100] Andasol Solar Power Station, Spain.

http://www.power-technology.com/projects/andasolsolarpower/

[Accessed 16.11.2012].

[101] Solar_thermal_power_stations.

http://en.wikipedia.org/wiki/List_of_solar_thermal_power_stations

[Accessed 16.11.2012].

[102] Palma del Rio I .

http://www.nrel.gov/csp/solarpaces/project_detail.cfm/projectID=16

[Accessed 16.11.2012].

[103] Palma del Rio II .

http://www.nrel.gov/csp/solarpaces/project_detail.cfm/projectID=6

[Accessed 16.11.2012].

[104] Manchasol-1. http://www.nrel.gov/csp/solarpaces/project_detail.cfm/projectID=7 [Accessed 16.11.2012].

[105] Manchasol-2. http://www.nrel.gov/csp/solarpaces/project_detail.cfm/projectID=8 [Accessed 16.11.2012].

[106] Valle Solar Power Station.

http://en.wikipedia.org/wiki/Valle_Solar_Power_Station

[Accessed 16.11.2012].

[107] Valle 1 (Arcosol 50).

http://www.nrel.gov/csp/solarpaces/project_detail.cfm/projectID=12

[Accessed 16.11.2012].

[108] Valle 2 (Termesol 50).

http://www.nrel.gov/csp/solarpaces/project_detail.cfm/projectID=13

[Accessed 16.11.2012].

[109] Helioenergy I and II.

http://www.tfkable.com/en/case-studies/helioenergy-i-and-ii.html

[Accessed 16.11.2012].

[110] Helioenergy I .

http://www.nrel.gov/csp/solarpaces/project_detail.cfm/projectID=47

[Accessed 16.11.2012].

[111] Helioenergy II .

http://www.nrel.gov/csp/solarpaces/project_detail.cfm/projectID $=48$

[Accessed 16.11.2012].

[112] Aste 1A. http://www.nrel.gov/csp/solarpaces/project_detail.cfm/projectID=215 [Accessed 16.11.2012].

[113] Aste 1B. http://www.nrel.gov/csp/solarpaces/project_detail.cfm/projectID=215 [Accessed 16.11.2012]. 
[114] Solacor 1. http://www.nrel.gov/csp/solarpaces/project_detail.cfm/projectID=223 [Accessed 16.11.2012].

[115] Solacor 2. http://www.nrel.gov/csp/solarpaces/project_detail.cfm/projectID=224 [Accessed 16.11.2012].

[116] Extresol. http://www.estelasolar.eu/index.php?id=47

[Accessed 16.11.2012].

[117] Extresol-1. http://www.nrel.gov/csp/solarpaces/project_detail.cfm/projectID=10 [Accessed 16.11.2012].

[118] Extresol-2. http://www.nrel.gov/csp/solarpaces/project_detail.cfm/projectID=11 [Accessed 16.11.2012].

[119] Extresol-3. http://www.nrel.gov/csp/solarpaces/project_detail.cfm/projectID=14 [Accessed 16.11.2012].

[120] Ibersol Ciudad Real (Puertollano).

http://www.nrel.gov/csp/solarpaces/project_detail.cfm/projectID $=18$

[Accessed 16.11.2012].

[121] Alvarado I. http://en.wikipedia.org/wiki/Alvarado_I

[Accessed 16.11.2012].

[122] La Florida Solar Power Plant.

http://www.power-technology.com/projects/lafloridasolarpowerp/

[Accessed 16.11.2012].

[123] La Florida.http://www.nrel.gov/csp/solarpaces/project_detail.cfm/projectID=27 [Accessed 16.11.2012].

[124] Majadas I. http://www.nrel.gov/csp/solarpaces/project_detail.cfm/projectID=9 [Accessed 16.11.2012].

[125] Solar Industry in Spain by Markel Redondo. http://fotodocument.smugmug.com/Other/Solar-Industry-inSpain/22910091_2WVJZB/1841389123_sf45FNK\#! $i=1841389123 \& k=s f 45 F N K$ [Accessed 16.11.2012].

[126] La Dehesa. http://www.nrel.gov/csp/solarpaces/project_detail.cfm/projectID=26 [Accessed 16.11.2012].

[127] Puerto Errado. http://en.wikipedia.org/wiki/Puerto_Errado

[Accessed 16.11.2012].

[128] Puerto Errado 2 Thermosolar Power Plant.

http://www.nrel.gov/csp/solarpaces/project_detail.cfm/projectID=159

[Accessed 16.11.2012].

[129] Osuna R. PS 10 and PS 20 Power Towers in Seville, Spain. NREL CSP

Technology Workshop, 2007. Available at:

http://www.nrel.gov/csp/troughnet/pdfs/2007/osuna_ps10-20_power_towers.pdf

[Accessed 16.11.2012].

[130] Planta Solar 20 (PS20).

http://www.nrel.gov/csp/solarpaces/project_detail.cfm/projectID=39

[Accessed 16.11.2012]. 
[131] Planta Solar 10 (PS10).

http://www.nrel.gov/csp/solarpaces/project_detail.cfm/projectID=38

[Accessed 16.11.2012].

[132]Puerto Errado 1 Thermosolar Power Plant.

http://www.nrel.gov/csp/solarpaces/project_detail.cfm/projectID $=46$

[Accessed 16.11.2012].

[133] Solar Energy Generating Systems.

http://en.wikipedia.org/wiki/Solar_Energy_Generating_Systems

[Accessed 16.11.2012].

[134] Solar power plants in the Mojave Desert.

http://en.wikipedia.org/wiki/Solar_power_plants_in_the_Mojave_Desert

[Accessed 16.11.2012].

[135] Solar Electric Generating Systems (all 9 units).

http://www.nrel.gov/csp/solarpaces/project_detail.cfm/projectID=28 (39), (30), (31),

(32), (33), (34), (35), (36)

[Accessed 16.11.2012].

[136] Martin Next Generation Solar Energy

Center.http://www.nrel.gov/csp/solarpaces/project_detail.cfm/projectID=267

[Accessed 16.11.2012].

[137] Nevada Solar One.

http://www.nrel.gov/csp/solarpaces/project_detail.cfm/projectID=20

[Accessed 16.11.2012].

[138] Kimberlina Solar Thermal Power Plant. AREVA® Report. available at:

http://www.areva.com/mediatheque/liblocal/docs/pdf/activites/energ-

renouvelables/Areva_Kimberlina_flyer.pdf

[Accessed 16.11.2012].

[139] Kimberlina Solar Thermal Power Plant, NREL database.

http://www.nrel.gov/csp/solarpaces/project_detail.cfm/projectID=37

[Accessed 16.11.2012].

[140] Sierra SunTower, NREL database.

http://www.nrel.gov/csp/solarpaces/project_detail.cfm/projectID=63

[Accessed 16.11.2012].

[141] Holaniku at Keahole Point, NREL database.

http://www.nrel.gov/csp/solarpaces/project_detail.cfm/projectID=71

[Accessed 16.11.2012].

[142] Maricopa Solar Project, NREL database.

http://www.nrel.gov/csp/solarpaces/project_detail.cfm/projectID=58

[Accessed 16.11.2012].

[143] Saguaro Power Plant, NREL database.

http://www.nrel.gov/csp/solarpaces/project_detail.cfm/projectID=24

[Accessed 16.11.2012].

[144] Tahani MA. The Integrated Solar Combined Cycle (ISCC) Power Plant Project in

Yazd, Iran. Conference presentation, In: International Executive Conference on

Expanding the Market for Concentrating Solar Power; Berlin, Germany, 2002. 
Available at: http://www.solarpaces.org/berlin_conference/Presentation-Tahani.pdf [Accessed 16.11.2012].

[145] Yaghoubi, MU, Armodly U, Kanan P. Shiraz Solar Thermal Power Plant Construction and steam generation. Shiraz University report, 2006. Available at: http://www.shirazu.ac.ir/files/extract_file.php?file_id=2006 [Accessed 16.11.2012].

[146] Archimede. http://www.nrel.gov/csp/solarpaces/project_detail.cfm/projectID=19 [Accessed 16.11.2012].

[147] Liddell Power Station. http://en.wikipedia.org/wiki/Liddell_Power_Station [Accessed 16.11.2012].

[148] Liddell Thermal Power Station - greening coal-fired power.

http://ecogeneration.com.au/news/liddell_thermal_power_station_-_greening_coal-

fired_power/002076/

[Accessed 16.11.2012].

[149] Jülich Solar Tower.

http://www.nrel.gov/csp/solarpaces/project_detail.cfm/projectID=246

[Accessed 16.11.2012].

[150] Abengoa Solar official website:

http://www.abengoasolar.com/corp/web/en/technologies/concentrated_solar_power/iscc /index.html

[Accessed 16.11.2012].

[151] Nezammahalleh H, Farhadi F, Tanhaemami M. Conceptual design and technoeconomic assessment of integrated solar combined cycle system with DSG technology. Sol. Energy 2010;84:1696-1705.

[152] Ivanpah Solar Power Facility.

http://en.wikipedia.org/wiki/Ivanpah_Solar_Power_Facility

[Accessed 16.11.2012].

[153] Ivanpah Solar Electric Generating Station Facility, NREL Report. http://www.nrel.gov/csp/solarpaces/project_detail.cfm/projectID=62 [Accessed 16.11.2012].

[154] Solana Generating Station.

http://www.nrel.gov/csp/solarpaces/project_detail.cfm/projectID=23

[Accessed 16.11.2012].

[155] Genesis Solar Energy Project.

http://www.nrel.gov/csp/solarpaces/project_detail.cfm/projectID=54

[Accessed 16.11.2012].

[156] Ashalim Sun PV Wins Tender for Planning, Financing and Building Photovoltaic Power Plant in Ashalim. Government report from International Affairs Department, Israel, 2012. Available at:

http://www.google.co.uk/url?sa=t\&rct=j\&q=\&esrc=s\&source=web\&cd=1\&cad=rja\&ve $\mathrm{d}=0 \mathrm{CB} 8 \mathrm{QFj} \mathrm{AA} \& \mathrm{url}=\mathrm{http} \% 3 \mathrm{~A} \% 2 \mathrm{~F} \% 2 \mathrm{Fwww}$.financeisrael.mof.gov.i1\%2FFinanceIsrae 1\%2FDocs\%2FEn\%2FpressReleases\%2F20120305.doc\&ei=sVWmUIawB4ej0QXwtIB w\&usg=AFQjCNGX0ET91g5OTP1cxybbyEbOr9PqBA\&sig2=9Y8wDVX_uQ0psKjiz wscoA

[Accessed 16.11.2012]. 
[157] Crescent Dunes Solar Energy Project.

http://www.nrel.gov/csp/solarpaces/project_detail.cfm/projectID=60

[Accessed 16.11.2012].

[158] Solaben 1 and Solaben 6.

http://www.nrel.gov/csp/solarpaces/project_detail.cfm/projectID=230 (233)

[Accessed 16.11.2012].

[159] Termosol 1.

http://www.nrel.gov/csp/solarpaces/project_detail.cfm/projectID=238

[Accessed 16.11.2012].

[160] Termosol 2.

http://www.nrel.gov/csp/solarpaces/project_detail.cfm/projectID=239

[Accessed 16.11.2012].

[161] Wu ZG, Zhao CY. Experimental investigations of porous materials in high temperature thermal energy storage systems. Sol. Energy 2011;85:1371-1380. 


\section{Table Captions}

Table 1: Typical design values of receiver peak flux.

Table 2: Design criteria of a solar thermal energy storage system

Table 3: Solid-state sensible heat storage materials [11].

Table 4: Molten salts and high temperature oils [11].

Table 5: Commercial PCMs materials and inorganic salts $[11,70]$.

Table 6: Materials used as chemical energy storage media.

Table 7: Existing solar thermal power stations.

Table 8: Solar thermal power stations under construction. 


\section{Table 1}

Typical design values of receiver peak flux.

\begin{tabular}{lll}
\hline Heat Transfer Fluid & Configuration & Peak Flux $\left(\mathrm{MW} / \mathrm{m}^{2}\right)$ \\
\hline Liquid sodium & In tubes & 1.50 \\
Liquid sodium & In heat pipes (transferring to air) & 1.20 \\
Molten nitrate salt & In tubes & 0.70 \\
Liquid water & In tubes & 0.70 \\
Steam vapor & In tubes & 0.50 \\
Air & In metal tubes & 0.22
\end{tabular}


Table 2

Design criteria of a solar thermal energy storage system.

\begin{tabular}{|c|c|}
\hline Criteria & Influencing factors \\
\hline \multirow[t]{6}{*}{ Technical criteria } & 1. High thermal energy storage capacity (the most important); \\
\hline & 2. Efficient heat transfer rate between HTF and storage material; \\
\hline & 3. Good mechanical and chemical stability of storage material; \\
\hline & 4. Compatibility between HTF, heat exchanger and/ or storage material; \\
\hline & $\begin{array}{l}\text { 5. Complete reversibility of a large number of charging and discharging } \\
\text { cycles; }\end{array}$ \\
\hline & 6. Low thermal losses and ease of control. \\
\hline \multirow{3}{*}{$\begin{array}{l}\text { Cost-effectiveness } \\
\text { criteria }\end{array}$} & 1. The cost of thermal energy storage materials; \\
\hline & 2. The cost of the heat exchanger; \\
\hline & 3. The cost of the space and/ or enclosure for the thermal energy storage. \\
\hline \multirow[t]{4}{*}{ Environmental criteria } & 1. Operation strategy; \\
\hline & 2. Maximum load; \\
\hline & 3. Nominal temperature and specific enthalpy drop in load; \\
\hline & 4. Integration to the power plant. \\
\hline
\end{tabular}


Table 3

Solid-state sensible heat storage materials. [11]

\begin{tabular}{|c|c|c|c|c|c|c|c|}
\hline $\begin{array}{l}\text { Storage } \\
\text { materials }\end{array}$ & $\begin{array}{l}\text { Working } \\
\text { Temperature } \\
{\left[{ }^{\circ} \mathrm{C}\right]}\end{array}$ & $\begin{array}{l}\text { Density } \\
{\left[\mathrm{kg} / \mathrm{m}^{3}\right]}\end{array}$ & $\begin{array}{l}\text { Thermal } \\
\text { conductivity } \\
{[\mathrm{W} /(\mathrm{m} \mathrm{K})]}\end{array}$ & $\begin{array}{l}\text { Specific } \\
\text { heat } \\
{[\mathrm{kJ} /(\mathrm{kg}} \\
\left.\left.{ }^{\circ} \mathrm{C}\right)\right]\end{array}$ & $\begin{array}{l}\text { Specific } \\
\text { heat } \\
{\left[\mathrm{kWh}_{\mathrm{t}} /\left(\mathrm{m}^{3}\right.\right.} \\
\left.\left.{ }^{\circ} \mathrm{C}\right)\right]\end{array}$ & $\begin{array}{l}\text { Cost per } \\
\mathrm{kg} \\
{[\mathrm{US} \$ / \mathrm{kg}]}\end{array}$ & $\begin{array}{l}\text { Cost per } \\
\mathrm{kWh}_{\mathrm{t}} \\
{\left[\mathrm{US} \$ / \mathrm{kWh}_{\mathrm{t}}\right]}\end{array}$ \\
\hline $\begin{array}{l}\text { Sand-rock } \\
\text { minerals }\end{array}$ & $200-300$ & 1700 & 1.0 & 1.30 & 0.61 & 0.15 & 4.2 \\
\hline $\begin{array}{l}\text { Reinforced } \\
\text { concrete }\end{array}$ & $200-400$ & 2200 & 1.5 & 0.85 & 0.52 & 0.05 & 1.0 \\
\hline Cast iron & $200-400$ & 7200 & 37.0 & 0.56 & 1.12 & 1.00 & 32.0 \\
\hline $\mathrm{NaCl}$ & $200-500$ & 2160 & 7.0 & 0.85 & 0.51 & 0.15 & 1.5 \\
\hline Cast steel & $200-700$ & 7800 & 40.0 & 0.60 & 1.30 & 5.00 & 60.0 \\
\hline $\begin{array}{l}\text { Silica fire } \\
\text { bricks }\end{array}$ & $200-700$ & 1820 & 1.5 & 1.00 & 0.51 & 1.00 & 7.0 \\
\hline $\begin{array}{l}\text { Magnesia } \\
\text { fire bricks }\end{array}$ & $200-1200$ & 3000 & 5.0 & 1.15 & 0.96 & 2.00 & 6.0 \\
\hline
\end{tabular}


Table 4

Molten salts and high temperature oils [11].

\begin{tabular}{|c|c|c|c|c|c|c|c|}
\hline $\begin{array}{l}\text { Storage } \\
\text { materials }\end{array}$ & $\begin{array}{l}\text { Working } \\
\text { Temperature } \\
{\left[{ }^{\circ} \mathrm{C}\right]}\end{array}$ & $\begin{array}{l}\text { Density } \\
{\left[\mathrm{kg} / \mathrm{m}^{3}\right]}\end{array}$ & $\begin{array}{l}\text { Thermal } \\
\text { conductivi } \\
\text { ty }[\mathrm{W} /(\mathrm{m} \\
\mathrm{K})]\end{array}$ & $\begin{array}{l}\text { Specific } \\
\text { heat } \\
{[\mathrm{kJ} /(\mathrm{kg}} \\
\left.\left.{ }^{\circ} \mathrm{C}\right)\right]\end{array}$ & $\begin{array}{l}\text { Specific } \\
\text { heat } \\
{\left[\mathrm{kWh} /\left(\mathrm{m}^{3}\right.\right.} \\
\left.\left.{ }^{\circ} \mathrm{C}\right)\right]\end{array}$ & $\begin{array}{l}\text { Costs per } \\
\mathrm{kg} \\
{[\mathrm{US} \$ / \mathrm{kg}]}\end{array}$ & $\begin{array}{l}\text { Costs per } \\
\mathrm{kWh}_{\mathrm{t}} \\
{\left[\mathrm{US} \$ / \mathrm{kWh}_{\mathrm{t}}\right]}\end{array}$ \\
\hline $\begin{array}{l}\text { Hitec }^{\circledR} \\
\text { solar salt }\end{array}$ & $220-600$ & 1899 & n.a. & 1.5 & 0.79 & 0.93 & 10.7 \\
\hline $\begin{array}{l}\text { HitecXL }^{\circledR} \\
\text { solar salt }\end{array}$ & $120-500$ & 1992 & 0.52 & 1.4 & 0.77 & 1.19 & 13.1 \\
\hline $\begin{array}{l}\text { Mineral } \\
\text { oil }\end{array}$ & $200-300$ & 770 & 0.12 & 2.6 & 0.56 & 0.30 & 4.2 \\
\hline $\begin{array}{l}\text { Synthetic } \\
\text { oil }\end{array}$ & $250-350$ & 900 & 0.11 & 2.3 & 0.58 & 3.00 & 43.0 \\
\hline $\begin{array}{l}\text { Silicone } \\
\text { oil }\end{array}$ & $300-400$ & 900 & 0.10 & 2.1 & 0.53 & 5.00 & 80.0 \\
\hline $\begin{array}{l}\text { Nitrite } \\
\text { salts }\end{array}$ & $250-450$ & 1825 & 0.57 & 1.5 & 0.76 & 1.00 & 12.0 \\
\hline $\begin{array}{l}\text { Liquid } \\
\text { sodium }\end{array}$ & $270-530$ & 850 & 71.0 & 1.3 & 0.31 & 2.00 & 21.0 \\
\hline $\begin{array}{l}\text { Nitrate } \\
\text { salts }\end{array}$ & $265-565$ & 1870 & 0.52 & 1.6 & 0.83 & 0.50 & 3.7 \\
\hline $\begin{array}{l}\text { Carbonate } \\
\text { salts }\end{array}$ & $450-850$ & 2100 & 2.0 & 1.8 & 1.05 & 2.40 & 11.0 \\
\hline
\end{tabular}

n.a.: not available. 
Table 5

Commercial PCMs materials, inorganic salts and eutectics $[11,70]$.

\begin{tabular}{|c|c|c|c|c|c|c|}
\hline $\begin{array}{l}\text { Storage } \\
\text { materials }\end{array}$ & $\begin{array}{l}\text { Phase } \\
\text { change } \\
\text { temperature } \\
\left({ }^{\circ} \mathrm{C}\right)\end{array}$ & $\begin{array}{l}\text { Density } \\
\left(\mathrm{kg} / \mathrm{m}^{3}\right)\end{array}$ & $\begin{array}{l}\text { Thermal } \\
\text { conductivity } \\
(\mathrm{W} / \mathrm{m} \mathrm{K})\end{array}$ & $\begin{array}{l}\text { Specific } \\
\text { heat }(\mathrm{kJ} / \mathrm{kg} \\
\mathrm{K})\end{array}$ & $\begin{array}{l}\text { Latent heat } \\
(\mathrm{kJ} / \mathrm{kg})\end{array}$ & $\begin{array}{l}\text { Latent heat } \\
\left(\mathrm{MJ} / \mathrm{m}^{3}\right)\end{array}$ \\
\hline $\begin{array}{l}\text { RT100 } \\
\text { (paraffin) }\end{array}$ & 100 & 880 & 0.20 & n.a. & 124 & n.a. \\
\hline $\begin{array}{l}\text { RT110 } \\
\text { (paraffin) }\end{array}$ & 112 & n.a. & n.a. & n.a. & 213 & n.a. \\
\hline $\begin{array}{l}\text { E117 } \\
\text { (inorganic) }\end{array}$ & 117 & 1450 & 0.70 & 2.61 & 169 & 245 \\
\hline $\begin{array}{l}\text { A164 } \\
\text { (organic) }\end{array}$ & 164 & 1500 & n.a. & n.a. & 306 & 459 \\
\hline $\mathrm{NaNO}_{3}$ & 307 & 2260 & 0.5 & n.a & 172 & 389 \\
\hline $\mathrm{KNO}_{3}$ & 333 & 2110 & 0.5 & n.a & 226 & 477 \\
\hline $\mathrm{KOH}$ & 380 & 2044 & 0.5 & n.a & 149.7 & 306 \\
\hline $\mathrm{AlSi}_{12}$ & 576 & 2700 & 1.6 & 1.04 & 560 & 1512 \\
\hline $\mathrm{MgCl}_{2}$ & 714 & 2140 & n.a. & n.a. & 452 & 967 \\
\hline $\mathrm{NaCl}$ & 800 & 2160 & 5 & n.a & 492 & 1063 \\
\hline $\mathrm{LiF}$ & 850 & n.a & n.a & n.a & n.a & 1800 \\
\hline $\mathrm{Na}_{2} \mathrm{CO}_{3}$ & 854 & 2533 & 2 & n.a & 275.7 & 698 \\
\hline $\mathrm{K}_{2} \mathrm{CO}_{3}$ & 897 & 2290 & 2 & n.a & 235.8 & 540 \\
\hline $\begin{array}{l}48 \% \mathrm{CaCO}_{3^{-}} \\
45 \% \mathrm{KNO}_{3^{-}} \\
7 \% \mathrm{NaNO}_{3}\end{array}$ & 130 & n.a & n.a & n.a & n.a & n.a \\
\hline $\begin{array}{l}\mathrm{KNO}_{3-}^{-} \\
\mathrm{NaNO}_{2-}^{-} \\
\mathrm{NaNO}_{3}\end{array}$ & 141 & n.a & n.a & n.a & 275 & n.a \\
\hline $\begin{array}{l}\mathrm{LiNO}_{3-} \\
\mathrm{NaNO}_{3}\end{array}$ & 195 & n.a & n.a & n.a & 252 & n.a \\
\hline $\begin{array}{l}\mathrm{MgCl}_{2}-\mathrm{KCl}- \\
\mathrm{NaCl}\end{array}$ & 380 & 2044 & 0.5 & n.a & 149.7 & 306 \\
\hline
\end{tabular}

n.a.: not available. 
Table 6

Materials used as chemical energy storage media.

\begin{tabular}{|c|c|c|c|}
\hline Materials & $\begin{array}{l}\text { Temperature } \\
\text { range }\left({ }^{\circ} \mathrm{C}\right)\end{array}$ & $\begin{array}{l}\text { Enthalpy change during } \\
\text { chemical reaction }\end{array}$ & Chemical reaction \\
\hline Iron carbonate [74] & 180 & $2.6 \mathrm{GJ} / \mathrm{m}^{3}$ & $\mathrm{FeCO}_{3} \leftrightarrow \mathrm{FeO}+\mathrm{CO}_{2}$ \\
\hline $\begin{array}{l}\text { Methanolation } \\
\text { demethanolation [74] }\end{array}$ & $200-250$ & n.a. & $\mathrm{CH}_{3} \mathrm{OH} \leftrightarrow \mathrm{CO}+2 \mathrm{H}_{2}$ \\
\hline Metal hydrides & $200-300$ & $4 \mathrm{GJ} / \mathrm{m}^{3}$ & $\left(\right.$ Metal $\left.\mathrm{xH}_{2}\right) \leftrightarrow$ metal $\mathrm{yH}_{2}$ \\
\hline$[75]$ & & & $+(x-y) \mathrm{H}_{2}$ \\
\hline Ammonia & $400-500$ & $67 \mathrm{~kJ} / \mathrm{mol}$ & $\mathrm{NH}_{3}+\Delta \mathrm{H} \leftrightarrow 1 / 2 \mathrm{~N}_{2}+3 / 2 \mathrm{H}_{2}$ \\
\hline$[76]$ & & & \\
\hline Hydroxides, e.g. [75] & 500 & $3 \mathrm{GJ} / \mathrm{m}^{3}$ & $\mathrm{Ca}(\mathrm{OH})_{2} \leftrightarrow \mathrm{CaO}+\mathrm{H}_{2} \mathrm{O}$ \\
\hline Methane/water [75] & $500-1000$ & n.a. & $\mathrm{CH}_{4}+\mathrm{H}_{2} \mathrm{O} \leftrightarrow \mathrm{CO}+3 \mathrm{H}_{2}$ \\
\hline $\begin{array}{l}\text { Calcium carbonate }[75, \\
77]\end{array}$ & $800-900$ & $4.4 \mathrm{GJ} / \mathrm{m}^{3}$ & $\mathrm{CaCO}_{3} \leftrightarrow \mathrm{CaO}+\mathrm{CO}_{2}$ \\
\hline $\begin{array}{l}\text { Metal oxides ( } \mathrm{Zn} \text { and } \mathrm{Fe}) \\
{[78]}\end{array}$ & $2000-2500$ & n.a. & $\begin{array}{l}\text { 2-step water splitting using } \\
\mathrm{Fe}_{3} \mathrm{O}_{4} / \mathrm{FeO} \text { re-dox system }\end{array}$ \\
\hline $\begin{array}{l}\text { Aluminium ore alumina } \\
\text { [79] }\end{array}$ & $2100-2300$ & n.a. & n.a. \\
\hline
\end{tabular}

n.a.: not available. 
Table 7

Existing solar thermal power stations.

\begin{tabular}{|c|c|c|c|c|c|c|c|}
\hline $\begin{array}{l}\text { Capacity } \\
\text { (MW) }\end{array}$ & Name & Country & Location & $\begin{array}{l}\text { Technology } \\
\text { type }\end{array}$ & Heat transfer fluid & Thermal storage & Notes \\
\hline 150 & Solnova & Spain & Seville & $\begin{array}{l}\text { Parabolic } \\
\text { trough [92] }\end{array}$ & $\begin{array}{l}\text { Thermal oil, } \\
\text { up to } 393^{\circ} \mathrm{C} \text { [93-95] }\end{array}$ & $\begin{array}{l}\text { No storage in } 3 \text { units, } \\
\text { using fossil fuel as backup } \\
\text { [93-95] }\end{array}$ & $\begin{array}{l}3 \text { units: Solnova } 1 \text { [93], } \\
\text { Solnova } 3 \text { [94] and } \\
\text { Solnova } 4 \text { [95] (50 MW } \\
\text { each); } \\
\text { completed in 2009, } 2009 \\
\text { and } 2010 \text {, respectively }\end{array}$ \\
\hline 150 & $\begin{array}{l}\text { Andasol Solar } \\
\text { Power Station }\end{array}$ & Spain & Granada & $\begin{array}{l}\text { Parabolic } \\
\text { trough [96] }\end{array}$ & $\begin{array}{l}\text { Andasol-1 and 2: } \\
\text { Diphenyl/Biphenyl oxide } \\
\left(293^{\circ} \mathrm{C}-393^{\circ} \mathrm{C}\right)[97,98] \text {; } \\
\text { Andasol-3: thermal oil } \\
\left(293^{\circ} \mathrm{C}-393^{\circ} \mathrm{C}\right)[99]\end{array}$ & $\begin{array}{l}7.5 \text { hours of heat storage, } \\
\text { 2-tank indirect storage } \\
\text { using molten salts: } \\
60 \% \text { sodium nitrate and } \\
40 \% \text { potassium nitrate } \\
\text { [97-99] }\end{array}$ & $\begin{array}{l}3 \text { units: Andasol-1, } \\
\text { Andasol-2 and Andasol-3 } \\
\text { (50 MW each) [100]; } \\
\text { completed in 2008, } 2009 \\
\text { and } 2011 \text {, respectively }\end{array}$ \\
\hline 100 & $\begin{array}{l}\text { Palma del Rio } \\
\text { Solar Power } \\
\text { Station }\end{array}$ & Spain & Palma del Río & $\begin{array}{l}\text { Parabolic } \\
\text { trough [101] }\end{array}$ & $\begin{array}{l}\text { Diphenyl/Biphenyl oxide } \\
\text { in both units }\left(293{ }^{\circ} \mathrm{C}-\right. \\
\left.393^{\circ} \mathrm{C}\right)[102,103]\end{array}$ & $\begin{array}{l}\text { Palma del Rio I : no } \\
\text { storage [102] } \\
\text { Palma del Rio II : n.a. }\end{array}$ & $\begin{array}{l}2 \text { units (50 MW each): } \\
\text { Palma del Rio I and II, } \\
\text { completed in } 2011\end{array}$ \\
\hline 100 & $\begin{array}{l}\text { Manchasol } \\
\text { Power Station }\end{array}$ & Spain & $\begin{array}{l}\text { Alcázar de San } \\
\text { Juan }\end{array}$ & $\begin{array}{l}\text { Parabolic } \\
\text { trough } \\
{[104,105]}\end{array}$ & $\begin{array}{l}\text { Diphenyl/Biphenyl oxide } \\
\text { in both units }\left(293^{\circ} \mathrm{C}-\right. \\
\left.393^{\circ} \mathrm{C}\right)[104,105]\end{array}$ & $\begin{array}{l}7.5 \text { hours of heat storage, } \\
2 \text {-tank indirect storage } \\
\text { using molten salts: } \\
60 \% \text { sodium nitrate and } \\
40 \% \text { potassium nitrate } \\
{[104,105]}\end{array}$ & $\begin{array}{l}2 \text { units: Manchasol-1 and } \\
\text { Manchasol-2 } \\
\text { (50 MW each) }[104,105] \text {; } \\
\text { completed in } 2011\end{array}$ \\
\hline 100 & $\begin{array}{l}\text { Valle Solar } \\
\text { Power Station }\end{array}$ & Spain & $\begin{array}{l}\text { San José del } \\
\text { Valle }\end{array}$ & $\begin{array}{l}\text { Parabolic } \\
\text { trough [106] }\end{array}$ & n.a. & $\begin{array}{l}7.5 \text { hours of heat storage, } \\
2 \text {-tank indirect storage } \\
\text { using molten salts: } \\
60 \% \text { sodium nitrate and } \\
40 \% \text { potassium nitrate } \\
{[107,108]}\end{array}$ & $\begin{array}{l}2 \text { units (50 MW each): } \\
\text { Valle } 1 \text { (aka 'Arcosol 50') } \\
\text { [107] and } \\
\text { Valle } 2 \text { (aka 'Termesol } \\
50 \text { ') [108]; } \\
\text { completed in } 2011\end{array}$ \\
\hline 100 & Helioenergy & Spain & Écija & Parabolic & Thermal oil used in both & No storage, using fossil & 2 units (50 MW each): \\
\hline
\end{tabular}




\begin{tabular}{|c|c|c|c|c|c|c|c|}
\hline \multirow[t]{2}{*}{$\begin{array}{l}\text { Capacity } \\
\text { (MW) }\end{array}$} & Name & Country & Location & $\begin{array}{l}\text { Technology } \\
\text { type }\end{array}$ & Heat transfer fluid & Thermal storage & Notes \\
\hline & $\begin{array}{l}\text { Solar Power } \\
\text { Station }\end{array}$ & & & trough [109] & $\begin{array}{l}\text { units }\left(293^{\circ} \mathrm{C}-393^{\circ} \mathrm{C}\right) \\
{[110,111]}\end{array}$ & $\begin{array}{l}\text { fuel as backup } \\
{[110,111]}\end{array}$ & $\begin{array}{l}\text { Helioenergy I and } \\
\text { Helioenergy II ; } \\
\text { completed in } 2012\end{array}$ \\
\hline 100 & $\begin{array}{l}\text { Aste Solar Power } \\
\text { Station }\end{array}$ & Spain & $\begin{array}{l}\text { Alcázar de San } \\
\text { Juan }\end{array}$ & $\begin{array}{l}\text { Parabolic } \\
\text { trough [101] }\end{array}$ & $\begin{array}{l}\text { Thermal oil used in both } \\
\text { units }\left(293^{\circ} \mathrm{C}-393^{\circ} \mathrm{C}\right) \\
{[112,113]}\end{array}$ & $\begin{array}{l}8 \text { hours of heat storage, } \\
\text { 2-tank indirect storage } \\
\text { using molten salts: } \\
60 \% \text { sodium nitrate and } \\
40 \% \text { potassium nitrate } \\
{[112,113]}\end{array}$ & $\begin{array}{l}2 \text { units (50 MW each): } \\
\text { Aste 1A [112] and } \\
\text { Aste 1B [113]; } \\
\text { completed in } 2012\end{array}$ \\
\hline 100 & $\begin{array}{l}\text { Solacor Solar } \\
\text { Power Station }\end{array}$ & Spain & El Carpio & $\begin{array}{l}\text { Parabolic } \\
\text { trough [101] }\end{array}$ & $\begin{array}{l}\text { Thermal oil used in both } \\
\text { units }\left(293^{\circ} \mathrm{C}-393^{\circ} \mathrm{C}\right) \\
{[114,115]}\end{array}$ & $\begin{array}{l}\text { No storage } \\
{[114,115]}\end{array}$ & $\begin{array}{l}2 \text { units (50 MW each): } \\
\text { Solacor } 1[114] \text { and } \\
\text { Solacor } 2 \text { [115]; } \\
\text { completed in } 2012\end{array}$ \\
\hline 100 & $\begin{array}{l}\text { Extresol Solar } \\
\text { Power Station }\end{array}$ & Spain & $\begin{array}{l}\text { Torre de } \\
\text { Miguel } \\
\text { Sesmero } \\
\text { (Badajoz) }\end{array}$ & $\begin{array}{l}\text { Parabolic } \\
\text { trough [116] }\end{array}$ & $\begin{array}{l}\text { Diphenyl/Biphenyl oxide } \\
\text { in both units } \\
\left(293^{\circ} \mathrm{C}-393^{\circ} \mathrm{C}\right) \\
{[117-119]}\end{array}$ & $\begin{array}{l}7.5 \text { hours of heat storage, } \\
\text { 2-tank indirect storage } \\
\text { using molten salts: } \\
60 \% \text { sodium nitrate and } \\
40 \% \text { potassium nitrate } \\
{[117-119]}\end{array}$ & $\begin{array}{l}2 \text { units (50 MW each): } \\
\text { Extresol-1 and Extresol-2 } \\
\text { (completed in 2010) } \\
{[117,118] \text {. }} \\
\text { Extresol-3 expected to } \\
\text { finish in } 2012 \text { [119]. }\end{array}$ \\
\hline 50 & $\begin{array}{l}\text { Ibersol Ciudad } \\
\text { Real }\end{array}$ & Spain & $\begin{array}{l}\text { Puertollano, } \\
\text { Ciudad Real }\end{array}$ & $\begin{array}{l}\text { Parabolic } \\
\text { trough [101] }\end{array}$ & $\begin{array}{l}\text { Diphenyl/Biphenyl oxide } \\
\left(304^{\circ} \mathrm{C}-391^{\circ} \mathrm{C}\right)[120]\end{array}$ & n.a. & Completed in 2009 [120] \\
\hline 50 & Alvarado I & Spain & Badajoz & $\begin{array}{l}\text { Parabolic } \\
\text { trough }[121]\end{array}$ & $\begin{array}{l}\text { Diphenyl/Biphenyl oxide } \\
\left(293^{\circ} \mathrm{C}-393^{\circ} \mathrm{C}\right)[121]\end{array}$ & $\begin{array}{l}\text { No storage } \\
{[121]}\end{array}$ & $\begin{array}{l}\text { Alvarado I: } \\
\text { aka 'La Risca' } \\
\text { Completed in } 2009 \text { [121] }\end{array}$ \\
\hline 50 & La Florida & Spain & $\begin{array}{l}\text { Alvarado } \\
\text { (Badajoz) }\end{array}$ & $\begin{array}{l}\text { Parabolic } \\
\text { trough [122] }\end{array}$ & $\begin{array}{l}\text { Diphenyl/Biphenyl oxide } \\
\left(298^{\circ} \mathrm{C}-393^{\circ} \mathrm{C}\right) \\
{[123]}\end{array}$ & $\begin{array}{l}7.5 \text { hours of heat storage, } \\
\text { 2-tank indirect storage } \\
\text { using molten salts: } \\
60 \% \text { sodium nitrate and } \\
40 \% \text { potassium nitrate } \\
\text { [122] }\end{array}$ & Completed in 2010 \\
\hline 50 & $\begin{array}{l}\text { Majadas de } \\
\text { Tiétar }\end{array}$ & Spain & Caceres & $\begin{array}{l}\text { Parabolic } \\
\text { trough }\end{array}$ & $\begin{array}{l}\text { Diphenyl/Biphenyl oxide, } \\
\text { up to } 393^{\circ} \mathrm{C}\end{array}$ & n.a. & Completed in 2010 \\
\hline
\end{tabular}




\begin{tabular}{|c|c|c|c|c|c|c|c|}
\hline $\begin{array}{l}\text { Capacity } \\
\text { (MW) }\end{array}$ & Name & Country & Location & $\begin{array}{l}\text { Technology } \\
\text { type } \\
{[101,124]}\end{array}$ & Heat transfer fluid & Thermal storage & Notes \\
\hline 50 & La Dehesa & Spain & $\begin{array}{l}\text { La Garrovilla } \\
\text { (Badajoz) }\end{array}$ & $\begin{array}{l}\text { Parabolic } \\
\text { trough [125] }\end{array}$ & $\begin{array}{l}\text { Diphenyl/Biphenyl oxide } \\
\left(298^{\circ} \mathrm{C}-393^{\circ} \mathrm{C}\right) \\
{[126]}\end{array}$ & $\begin{array}{l}7 \text { hours [125] }-7.5 \text { hours } \\
\text { [126] of heat storage; } \\
\text { 2-tank indirect storage } \\
\text { using molten salts: } \\
60 \% \text { sodium nitrate and } \\
40 \% \text { potassium nitrate }\end{array}$ & Completed in 2010 \\
\hline 30 & Puerto Errado 2 & Spain & Murcia & $\begin{array}{l}\text { Fresnel } \\
\text { reflector } \\
{[127]}\end{array}$ & $\begin{array}{l}\text { Water }\left(140{ }^{\circ} \mathrm{C}-270^{\circ} \mathrm{C}\right) \\
{[128]}\end{array}$ & $\begin{array}{l}0.5 \text { hours of heat storage, } \\
\text { single-tank thermocline } \\
{[128]}\end{array}$ & Completed in 2012 \\
\hline 20 & $\begin{array}{l}\text { PS20 Solar } \\
\text { Power Tower }\end{array}$ & 5 Spain & Seville & $\begin{array}{l}\text { Solar power } \\
\text { tower [129] }\end{array}$ & $\begin{array}{l}\text { Water } \\
\left(250{ }^{\circ} \mathrm{C}-300^{\circ} \mathrm{C}\right) \\
{[130]}\end{array}$ & $\begin{array}{l}1 \text { hour of heat storage } \\
{[130] ;} \\
\text { storage type: n.a. }\end{array}$ & Completed in 2009 \\
\hline 11 & $\begin{array}{l}\text { PS10 Solar } \\
\text { Power Tower }\end{array}$ & Spain & Seville & $\begin{array}{l}\text { Solar power } \\
\text { tower [129] }\end{array}$ & $\begin{array}{l}\text { Water } \\
\left(250{ }^{\circ} \mathrm{C}-300^{\circ} \mathrm{C}\right) \\
{[131]}\end{array}$ & $\begin{array}{l}1 \text { hour of heat storage } \\
\text { [131]; } \\
\text { storage type: n.a. }\end{array}$ & $\begin{array}{l}\text { Completed in } 2007 \text {, the } \\
\text { World's first commercial } \\
\text { solar tower-type plant }\end{array}$ \\
\hline 1.4 & Puerto Errado 1 & $\therefore$ Spain & Murcia & $\begin{array}{l}\text { Fresnel } \\
\text { reflector } \\
{[127]}\end{array}$ & $\begin{array}{l}\text { Water }\left(140^{\circ} \mathrm{C}-270^{\circ} \mathrm{C}\right) \\
{[132]}\end{array}$ & $\begin{array}{l}\text { Storage capacity: n.a., } \\
\text { single-tank thermocline } \\
{[132]}\end{array}$ & Completed in 2009 \\
\hline 354 & $\begin{array}{l}\text { Solar Energy } \\
\text { Generating } \\
\text { Systems }\end{array}$ & 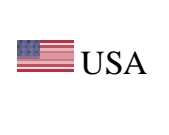 & $\begin{array}{l}\text { Mojave Desert } \\
\text { California }\end{array}$ & $\begin{array}{l}\text { Parabolic } \\
\text { trough } \\
{[133,134]}\end{array}$ & $\begin{array}{l}\text { Therminol }{ }^{\circledR} \text { fluid, } \\
\left(349^{\circ} \mathrm{C}-390^{\circ} \mathrm{C}\right) \\
{[135]}\end{array}$ & n.a. & $\begin{array}{l}9 \text { units, completed in } 1984 \\
\text { [133] }\end{array}$ \\
\hline 75 & $\begin{array}{l}\text { Martin Next } \\
\text { Generation Solar } \\
\text { Energy Center }\end{array}$ & 渴 USA & Florida & $\begin{array}{l}\text { Parabolic } \\
\text { trough, ISCC } \\
{[136]}\end{array}$ & $\begin{array}{l}\text { Thermal oil } \\
\text { [136] }\end{array}$ & $\begin{array}{l}\text { No storage } \\
{[136]}\end{array}$ & $\begin{array}{l}\text { Integrated Solar Combined } \\
\text { Cycle, completed in } 2010\end{array}$ \\
\hline 64 & $\begin{array}{l}\text { Nevada Solar } \\
\text { One }\end{array}$ & 嚚USA & $\begin{array}{l}\text { Boulder City, } \\
\text { Nevada }\end{array}$ & $\begin{array}{l}\text { Parabolic } \\
\text { trough [134] }\end{array}$ & $\begin{array}{l}\text { Dowtherm® fluid } \\
\text { [137] }\end{array}$ & $\begin{array}{l}0.5 \text { hours of heat storage } \\
{[137] \text {; }} \\
\text { storage type: n.a. }\end{array}$ & Completed in 2007 \\
\hline 5 & $\begin{array}{l}\text { Kimberlina Solar } \\
\text { Thermal Energy }\end{array}$ & $\underline{\underline{\underline{\underline{E}}}}$ USA & $\begin{array}{l}\text { Bakersfield, } \\
\text { California }\end{array}$ & $\begin{array}{l}\text { Fresnel } \\
\text { reflector }\end{array}$ & Water & No storage [139] & Completed in 2008 \\
\hline
\end{tabular}




\begin{tabular}{|c|c|c|c|c|c|c|c|}
\hline $\begin{array}{l}\text { Capacity } \\
\text { (MW) }\end{array}$ & Name & Country & Location & $\begin{array}{l}\text { Technology } \\
\text { type }\end{array}$ & Heat transfer fluid & Thermal storage & Notes \\
\hline & Plant & & & {$[138]$} & & & \\
\hline 5 & Sierra SunTower & 雪USA & Lancaster & $\begin{array}{l}\text { Solar power } \\
\text { tower }[134]\end{array}$ & $\begin{array}{l}\text { Water }\left(218^{\circ} \mathrm{C}-440^{\circ} \mathrm{C}\right) \\
{[140]}\end{array}$ & No storage [140] & Completed in 2009 \\
\hline 2 & $\begin{array}{l}\text { Keahole Solar } \\
\text { Power }\end{array}$ & 嚚USA & Hawaii & $\begin{array}{l}\text { Parabolic } \\
\text { trough [141] }\end{array}$ & $\begin{array}{l}\text { Xceltherm }{ }^{\circledR}-600 \\
\left(93{ }^{\circ} \mathrm{C}-176^{\circ} \mathrm{C}\right) \\
{[141]}\end{array}$ & $\begin{array}{l}2 \text { hours of heat storage } \\
\text { [141]; } \\
\text { storage type: n.a. }\end{array}$ & Completed in 2009 \\
\hline 1.5 & Maricopa Solar & 制USA & Peoria, Arizona & $\begin{array}{l}\text { Parabolic } \\
\text { Dish Stirling } \\
{[142]}\end{array}$ & n.a. & $\begin{array}{l}\text { No storage } \\
{[142]}\end{array}$ & Completed in 2010 \\
\hline 1 & $\begin{array}{l}\text { Saguaro Solar } \\
\text { Power Station }\end{array}$ & 彗USA & Red Rock & $\begin{array}{l}\text { Parabolic } \\
\text { trough } \\
{[143]}\end{array}$ & $\begin{array}{l}\text { Xceltherm }{ }^{\circledR}-600 \text { and } \\
\text { n-pentane }\left(120^{\circ} \mathrm{C}-\right. \\
\left.300^{\circ} \mathrm{C}\right) \\
{[143]}\end{array}$ & $\begin{array}{l}\text { No storage, using natural } \\
\text { gas as backup } \\
{[143]}\end{array}$ & Completed in 2006 \\
\hline 17 & $\begin{array}{l}\text { Yazd Integrated } \\
\text { Solar Combined } \\
\text { Cycle Power } \\
\text { Station }\end{array}$ & Iran & Yazd & $\begin{array}{l}\text { Parabolic } \\
\text { trough [144] }\end{array}$ & $\begin{array}{l}\text { Thermal oil } \\
{[144]}\end{array}$ & $\begin{array}{l}\text { No storage } \\
{[144]}\end{array}$ & $\begin{array}{l}\text { Completed in } 2009 \text {, the } \\
\text { World's first ISCC power } \\
\text { plant }\end{array}$ \\
\hline 0.25 & $\begin{array}{l}\text { Shiraz Solar } \\
\text { Power Plant }\end{array}$ & Iran & Shiraz & $\begin{array}{l}\text { Parabolic } \\
\text { trough [145] }\end{array}$ & $\begin{array}{l}\text { Thermal oil } \\
{[145]}\end{array}$ & $\begin{array}{l}\text { No storage, } \\
\text { using fossil fuels in the } \\
\text { night or cloudy times } \\
{[145]}\end{array}$ & $\begin{array}{l}\text { Completed in 2008, Iran's } \\
\text { first solar power plant, }\end{array}$ \\
\hline 5 & $\begin{array}{l}\text { Archimede Solar } \\
\text { Power Plant }\end{array}$ & Italy & $\begin{array}{l}\text { near Siracusa, } \\
\text { Sicily }\end{array}$ & $\begin{array}{l}\text { Parabolic } \\
\text { trough [146] }\end{array}$ & $\begin{array}{l}\text { Molten salts made of } 60 \% \\
\text { sodium nitrate and } 40 \% \\
\text { potassium nitrate } \\
\left(290{ }^{\circ} \mathrm{C}-550^{\circ} \mathrm{C}\right) \\
{[146]}\end{array}$ & $\begin{array}{l}8 \text { hours of heat storage, } \\
\text { 2-tank indirect storage } \\
\text { using molten salts: } \\
60 \% \text { sodium nitrate and } \\
40 \% \text { potassium nitrate } \\
\text { [146] }\end{array}$ & $\begin{array}{l}\text { Completed in } 2010 \text {, } \\
\text { ISCC with heat storage }\end{array}$ \\
\hline 2 & $\begin{array}{l}\text { Liddell Power } \\
\text { Station Solar } \\
\text { Steam Generator }\end{array}$ & Australia & $\begin{array}{l}\text { New South } \\
\text { Wales }\end{array}$ & $\begin{array}{l}\text { Fresnel } \\
\text { reflector } \\
{[147]}\end{array}$ & $\begin{array}{l}\text { Water } \\
{[148]}\end{array}$ & n.a. & $\begin{array}{l}\text { Completed in } 2007 \text {, } \\
\text { Mainly coal-fired, solar } \\
\text { energy only used to } \\
\text { preheat boiler feed water. } \\
{[148]}\end{array}$ \\
\hline
\end{tabular}




\begin{tabular}{|c|c|c|c|c|c|c|c|}
\hline $\begin{array}{l}\text { Capacity } \\
\text { (MW) }\end{array}$ & Name & Country & Location & $\begin{array}{l}\text { Technology } \\
\text { type }\end{array}$ & Heat transfer fluid & Thermal storage & Notes \\
\hline 1.5 & $\begin{array}{l}\text { Jülich Solar } \\
\text { Tower }\end{array}$ & Germany & Jülich & $\begin{array}{l}\text { Solar power } \\
\text { tower [149] }\end{array}$ & $\begin{array}{l}\text { Air, up to } 700{ }^{\circ} \mathrm{C} \\
\text { [149] }\end{array}$ & $\begin{array}{l}1.5 \text { hours of heat storage, } \\
\text { using ceramic heat sink } \\
\text { [149] }\end{array}$ & Completed in 2008 \\
\hline
\end{tabular}

n.a.: not available.

aka: also known as. 


\section{Table 8}

Solar thermal power stations under construction.

\begin{tabular}{|c|c|c|c|c|c|c|c|c|}
\hline $\begin{array}{l}\text { Capacity } \\
\text { (MW) }\end{array}$ & Name & Country & Location & $\begin{array}{l}\text { Technology } \\
\text { type }\end{array}$ & Heat transfer fluid & Thermal storage & Expected completion & Notes \\
\hline 400 & $\begin{array}{l}\text { Ivanpah Solar } \\
\text { Power Facility }\end{array}$ & 恝 USA & $\begin{array}{l}\text { San } \\
\text { Bernardino } \\
\text { County, } \\
\text { California }\end{array}$ & $\begin{array}{l}\text { Solar power } \\
\text { tower } \\
{[134,152]}\end{array}$ & $\begin{array}{l}\text { Water } \\
\left(249^{\circ} \mathrm{C}-566^{\circ} \mathrm{C}\right) \\
{[153]}\end{array}$ & $\begin{array}{l}\text { No storage, using } \\
\text { natural gas as backup } \\
{[153]}\end{array}$ & 2013 & $\begin{array}{l}3 \text { units [152]: } \\
\text { Ivanpah } 1,2 \text { and } 3 . \\
\text { Ivanpah } 1 \text { and } 2: 100 \\
\text { MW each } \\
\text { Ivanpah 3: } 200 \mathrm{MW}\end{array}$ \\
\hline 280 & $\begin{array}{l}\text { Solana } \\
\text { Generating } \\
\text { Station }\end{array}$ & $\underline{\underline{\underline{\underline{E}}}}$ USA & $\begin{array}{l}\text { West of Gila } \\
\text { Bend, AZ }\end{array}$ & $\begin{array}{l}\text { Parabolic } \\
\text { trough } \\
{[154]}\end{array}$ & $\begin{array}{l}\text { Material: n.a. } \\
\text { up to } 371^{\circ} \mathrm{C} \\
{[154]}\end{array}$ & $\begin{array}{l}\text { 6h heat storage } \\
\text { molten salts } \\
{[154]}\end{array}$ & 2013 & \\
\hline 250 & Genesis Solar & 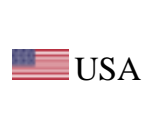 & $\begin{array}{l}\text { Blythe, } \\
\text { California }\end{array}$ & $\begin{array}{l}\text { Parabolic } \\
\text { trough } \\
{[155]}\end{array}$ & $\begin{array}{l}\text { Therminol }{ }^{\circledR} \mathrm{VP}-1 \text {, } \\
\text { up to } 393{ }^{\circ} \mathrm{C} \\
{[155]}\end{array}$ & $\begin{array}{l}\text { No storage, using } \\
\text { natural gas as backup } \\
{[155]}\end{array}$ & 2014 & $\begin{array}{l}2 \text { units: } 125 \mathrm{MW} \text { each } \\
{[155]}\end{array}$ \\
\hline 250 & $\begin{array}{l}\text { Ashalim } \\
\text { power station }\end{array}$ & $\overline{\overline{\dot{x}^{\prime}}}$ Israel & Negev desert & $\begin{array}{l}\text { Parabolic } \\
\text { trough } \\
{[156]}\end{array}$ & n.a. & $\begin{array}{l}\text { No storage, using } \\
\text { natural gas as backup } \\
{[156]}\end{array}$ & 2013 & $\begin{array}{l}\text { A combination of } \\
\text { two solar thermal units } \\
\text { (110 MW each) } \\
\text { and one PV unit: } \\
(30 \mathrm{MW}) \\
{[156]}\end{array}$ \\
\hline 110 & $\begin{array}{l}\text { Crescent } \\
\text { Dunes Solar } \\
\text { Energy } \\
\text { Project }\end{array}$ & 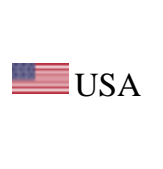 & $\begin{array}{l}\text { Nye County, } \\
\text { Nevada }\end{array}$ & $\begin{array}{l}\text { Solar power } \\
\text { tower [157] }\end{array}$ & $\begin{array}{l}\text { Molten salts, } \\
\left(288^{\circ} \mathrm{C}-566^{\circ} \mathrm{C}\right) \\
{[157]}\end{array}$ & $\begin{array}{l}\text { Molten salts, } \\
\text { with } 10 \text { hours of heat } \\
\text { storage [157] }\end{array}$ & $2013 / 14$ & \\
\hline 100 & Solaben & Spain & Logrosan & $\begin{array}{l}\text { Parabolic } \\
\text { trough } \\
{[158]}\end{array}$ & $\begin{array}{l}\text { Thermal oil } \\
\left(296{ }^{\circ} \mathrm{C}-393{ }^{\circ} \mathrm{C}\right) \\
{[158]}\end{array}$ & $\begin{array}{l}\text { No storage, using } \\
\text { natural gas as backup } \\
{[158]}\end{array}$ & 2013 & $\begin{array}{l}2 \text { units: Solaben } 1 \text { and } \\
\text { Solaben } 6 \\
(50 \mathrm{MW} \text { each })\end{array}$ \\
\hline
\end{tabular}


9 hours of heat

storage,

Navalvillar Parabolic Thermal oil 2-tank indirect storage

using molten salts:

2 units:

$60 \%$ sodium nitrate

2013

Termosol 1 [159] and

de Pela trough $\left(296{ }^{\circ} \mathrm{C}-393{ }^{\circ} \mathrm{C}\right)$

and $40 \%$ potassium

Termosol 2 [160]

nitrate

(50 MW each)

$[159,160]$

n.a.: not available. 


\section{Figure Captions}

Figure 1: The Earth's energy budget ([2], from NASA sources).

Figure 2: Schematic of the double-passage solar collector with porous media in second channel [25].

Figure 3: PV/T flow-passage models [43].

Figure 4: Optical spectra of water and Silicon parameters [55]:

(1) transmission characteristics of a water layer with thickness of $1.5 \mathrm{~cm}$,

(2) absorption characteristics of a typical c-Si layer with thickness of $50 \mu \mathrm{m}$.

Figure 5: Hourly variations of the short-circuit currents of the PV module: the rear face alone (curve 1), the front face (curve 2) and the total (curve 3) [55].

Figure 6: Two types of solar towers [60]: (a) external receiver; (b) Cavity receiver.

Figure 7: Use of carbon fibres to enhance heat transfer: (a) Fibre cloth; (b) Fibre brush; (c) No carbon fibre; (d) Fibre cloth of $142 \mathrm{~g} / \mathrm{m}^{2}$; (e) Fibre cloth of $304 \mathrm{~g} / \mathrm{m}^{2}$.

Figure 8: A comparison of thermal conductivity enhancement between the fibre brush and the random type [85].

Figure 9: Photograph of (a) pure paraffin as PCM; (b) paraffin/EG (10\% mass) composite as form-stable PCM [86].

Figure 10: Metal foams

(source: http://www.acceleratingfuture.com/michael/blog/category/images/page/4/).

Figure 11: Temperature differences $(\Delta T)$ between metal foams and expanded graphite [87].

Figure 12. Comparison of stored heat between sensible heat storage and latent heat storage [89]: (a) With a single PCM; (b) With cascaded latent heat storage.

Figure 13: Comparison between a single-stage storage system and a 5-stage cascaded storage system [70, 59]. 


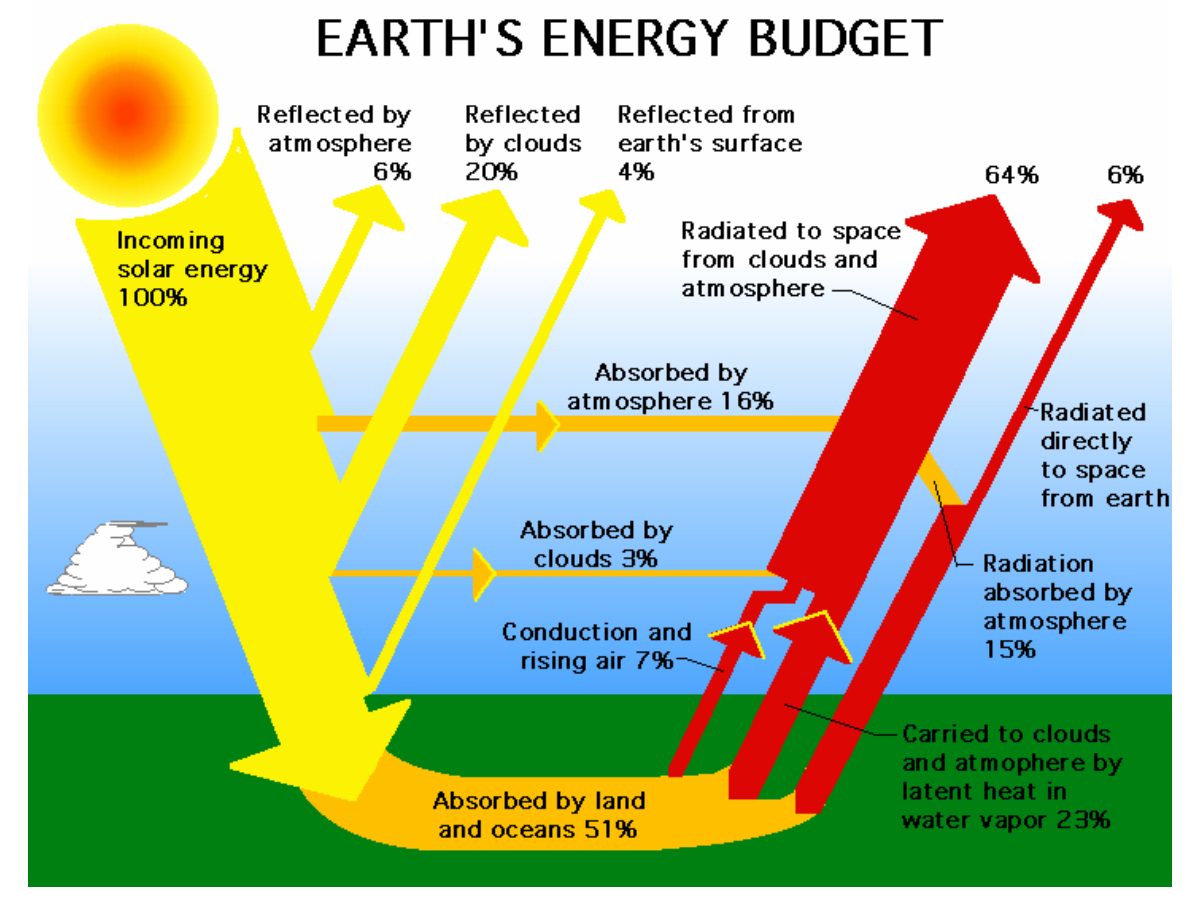

Fig. 1. The Earth's energy budget ([2], from NASA sources).

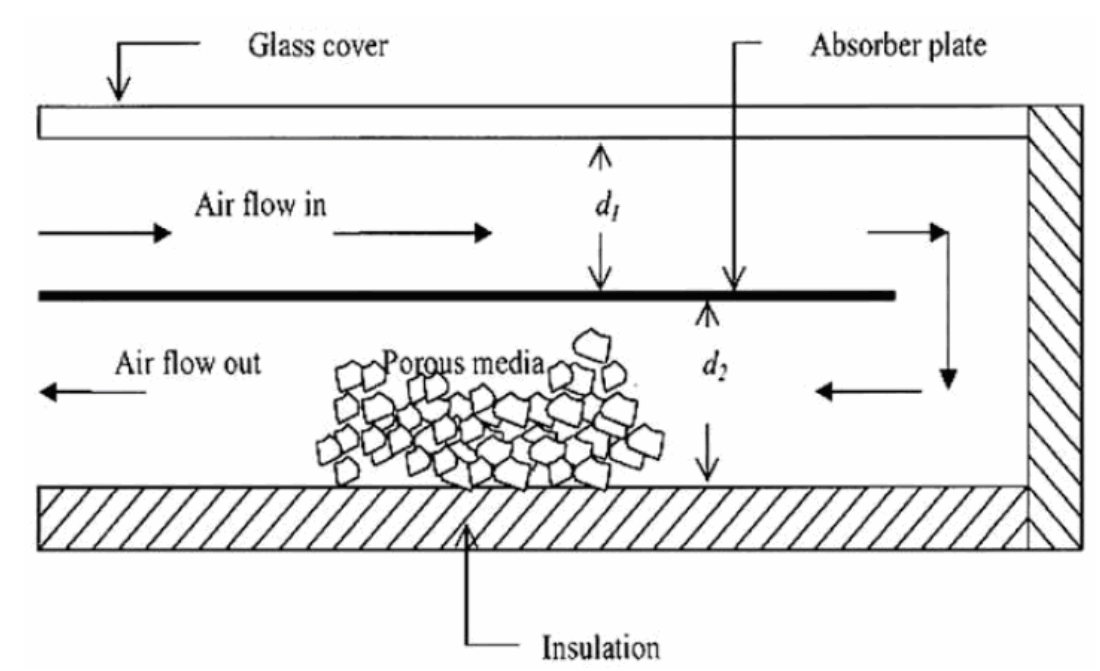

Fig. 2. Schematic of the double-passage solar collector with porous media in second channel [25]. 

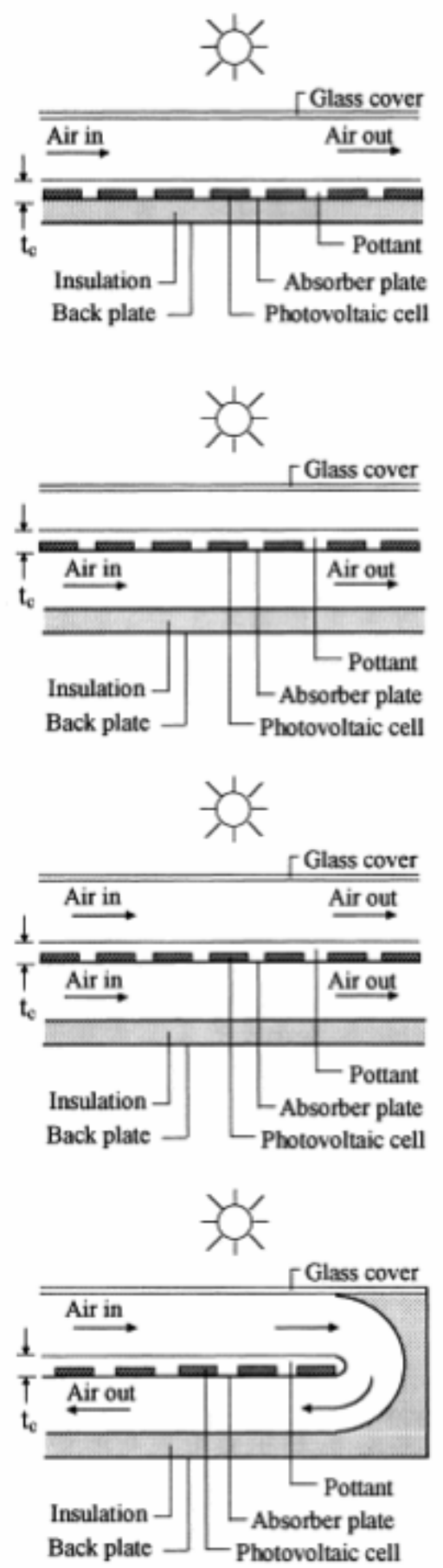

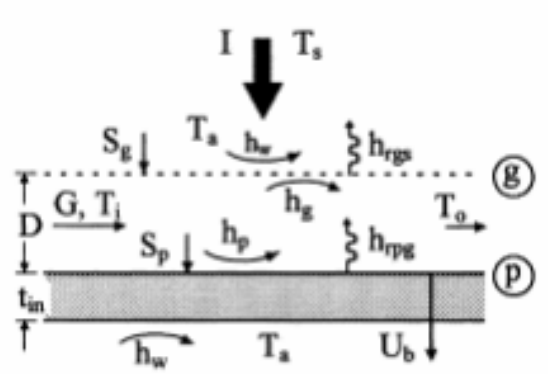

Model I

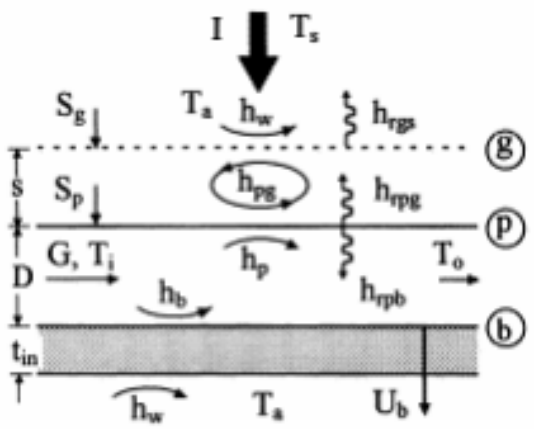

Model II

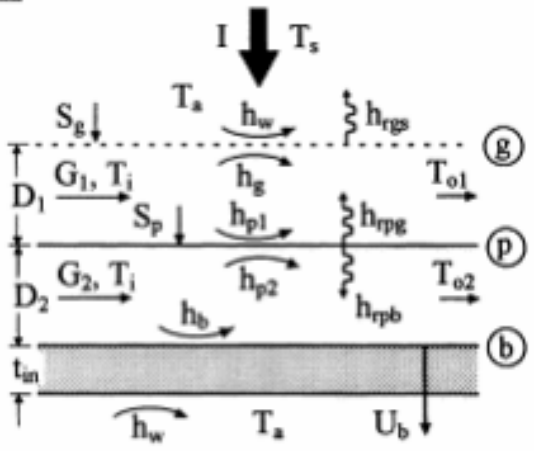

Model III

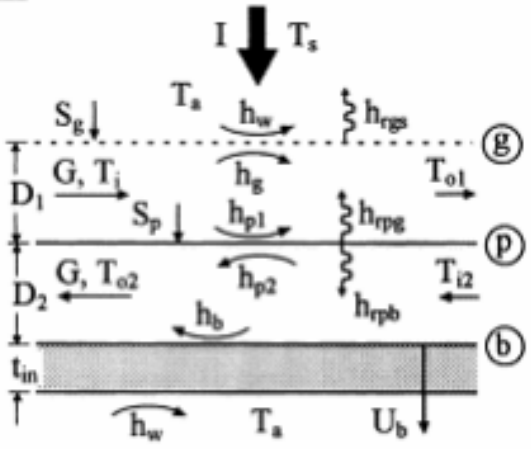

Model IV

Fig. 3. PV/T flow-passage models [43]. 


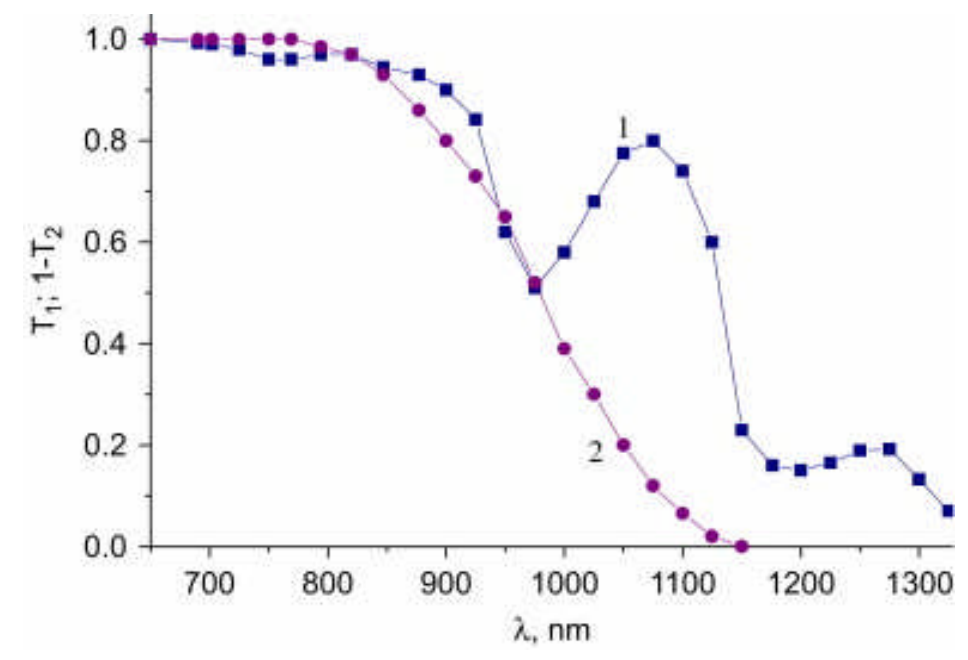

Fig. 4. Optical spectra of water and Silicon parameters [55]:

(1) transmission characteristics of a water layer with thickness of $1.5 \mathrm{~cm}$,

(2) absorption characteristics of a typical c-Si layer with thickness of $50 \mu \mathrm{m}$.

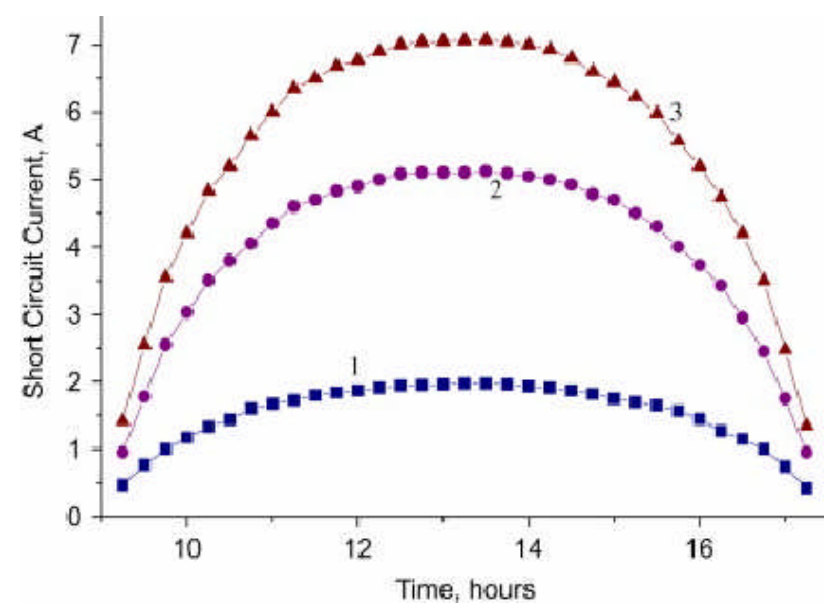

Fig. 5. Hourly variations of the short-circuit currents of the PV module: the rear face alone (curve 1), the front face (curve 2) and the total (curve 3) [55]. 


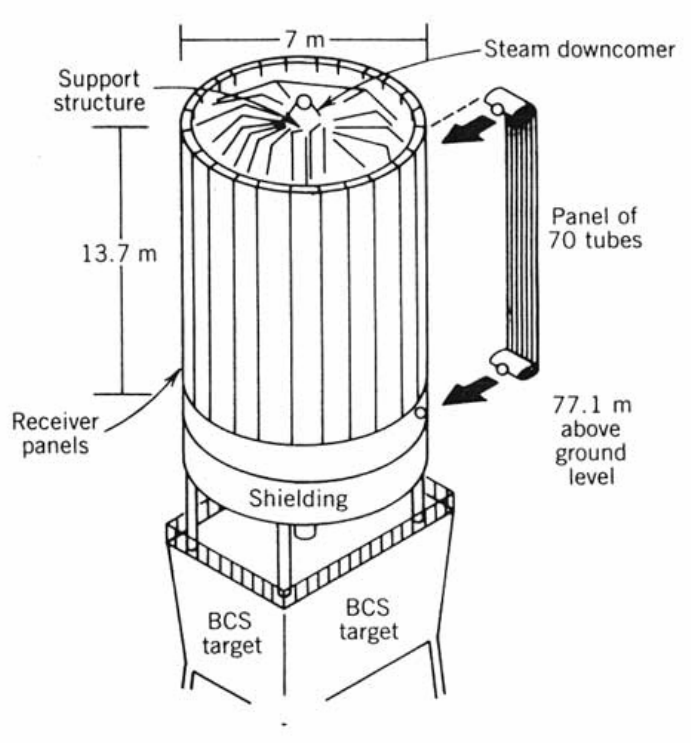

(a)

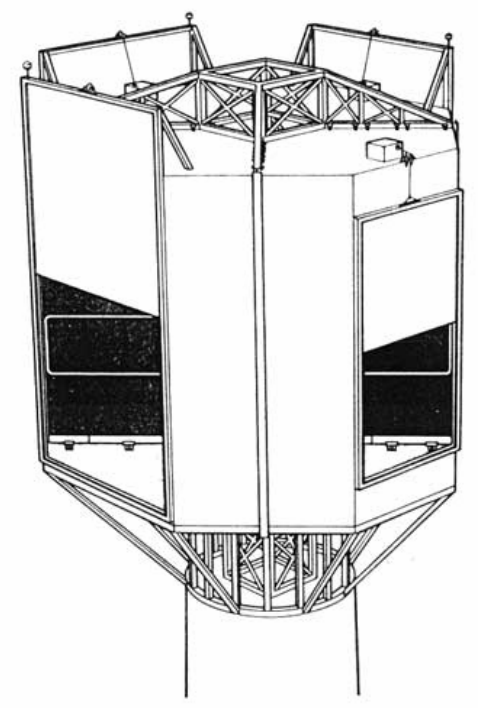

(b)

Fig. 6. Two types of solar towers [60]:

(a) External receiver; (b) Cavity receiver 


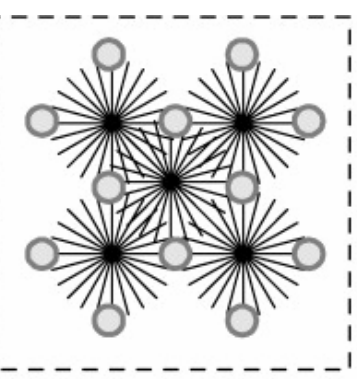

(b)

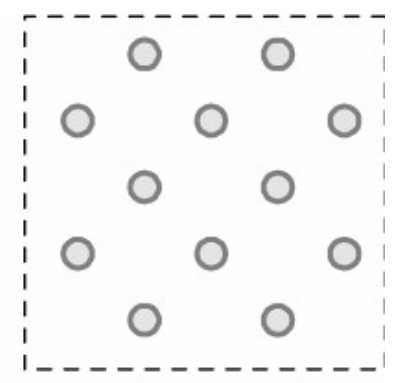

(c)

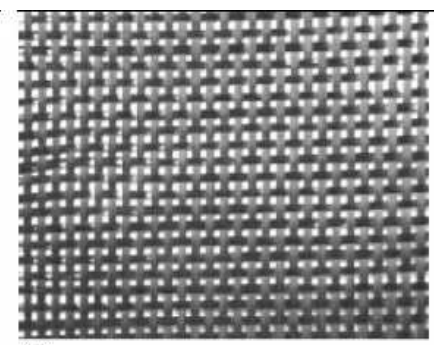

(d)

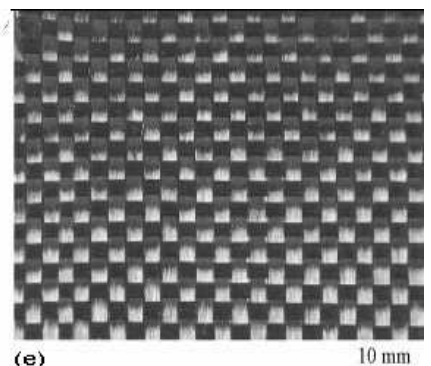

(e)

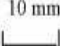

Fig. 7. Use of carbon fibres to enhance heat transfer [83].

(a) Fibre cloth; (b) Fibre brush; (c) No carbon fibre;

(d) Fibre cloth of $142 \mathrm{~g} / \mathrm{m}^{2}$; (e) Fibre cloth of $304 \mathrm{~g} / \mathrm{m}^{2}$.

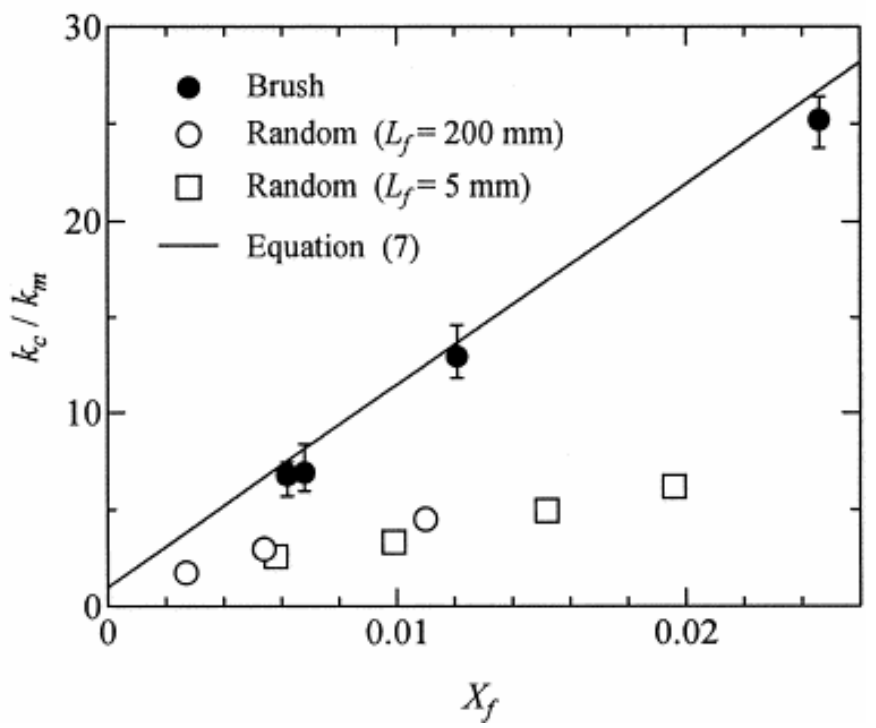

Fig. 8. A comparison of thermal conductivity enhancement between the fibre brush and the random type [83]. 


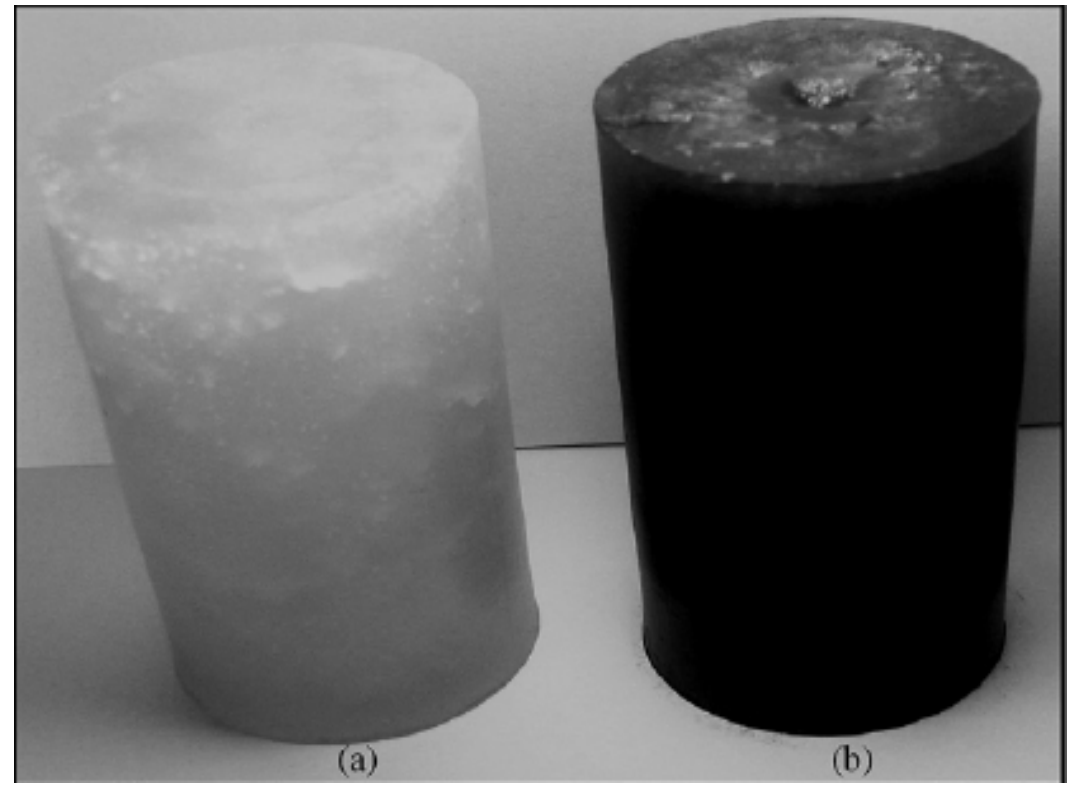

Fig. 9. Photograph of (a) pure paraffin as PCM; (b) paraffin/EG (10\% mass) composite as form-stable PCM [86]. 


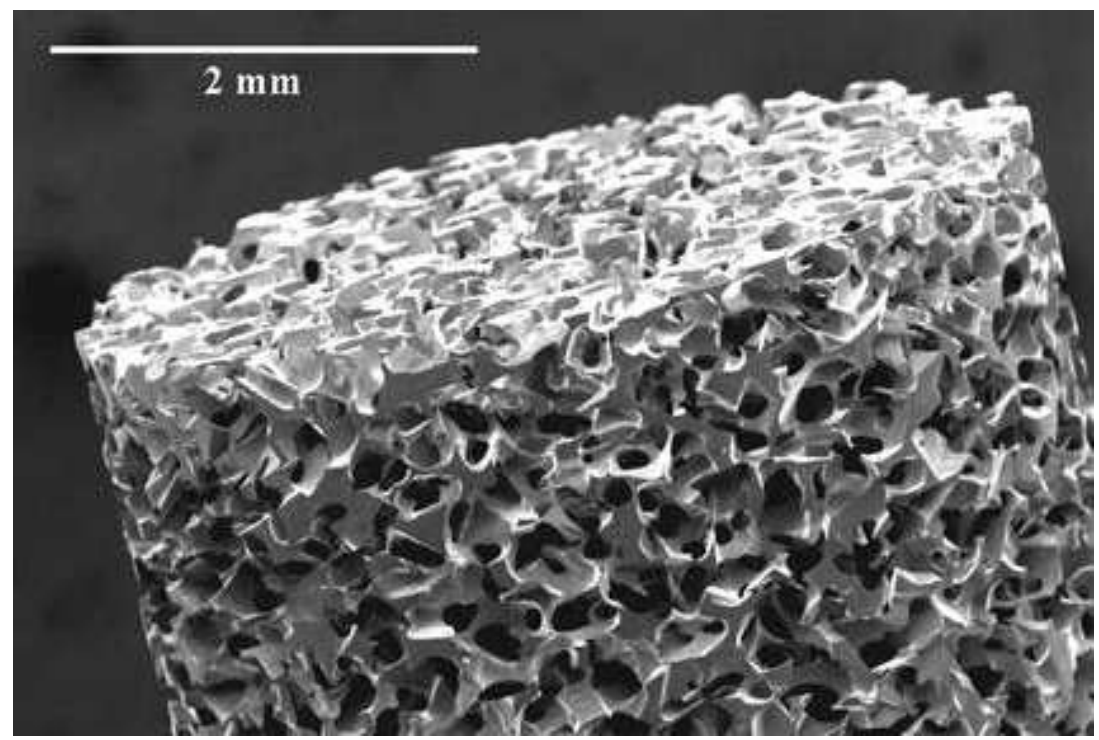

Fig. 10. Metal foams

(source: http://www.acceleratingfuture.com/michael/blog/category/images/page/4/).

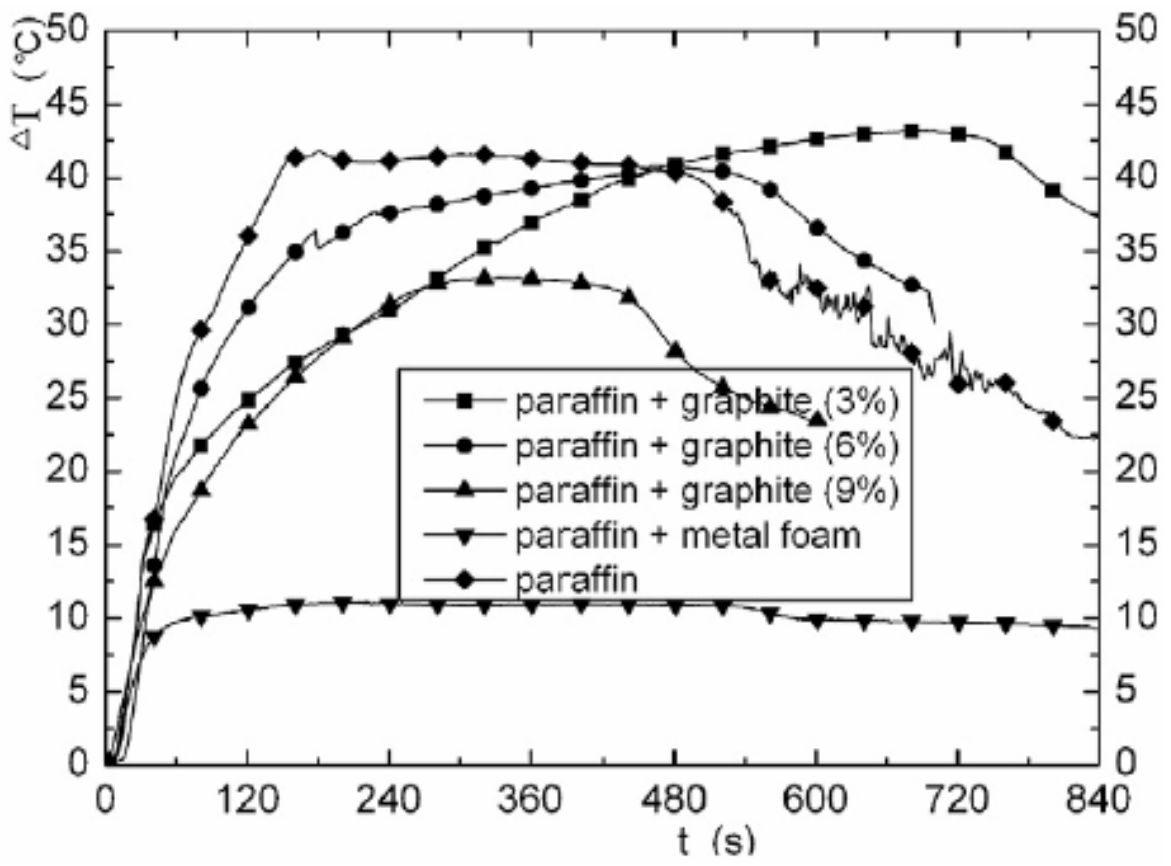

Fig. 11. Temperature differences $(\Delta T)$ between metal foams and expanded graphite [87]. 


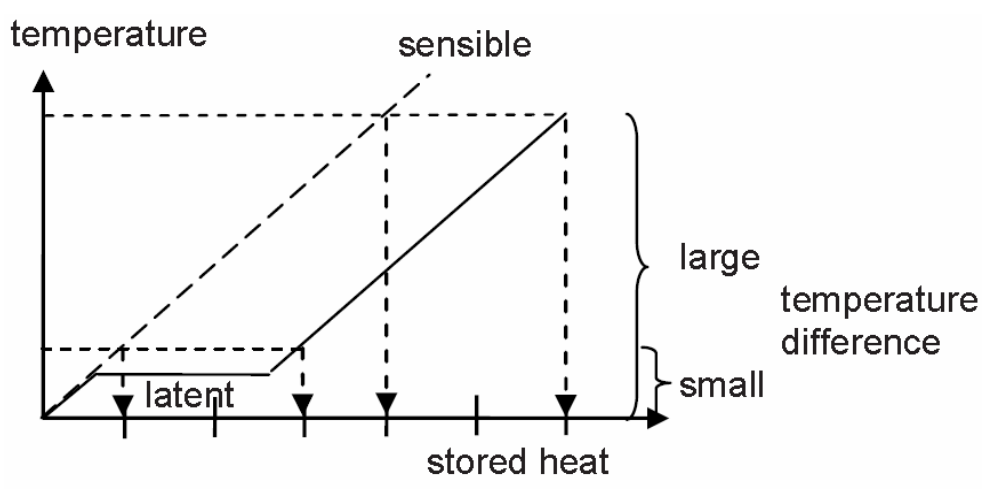

(a)

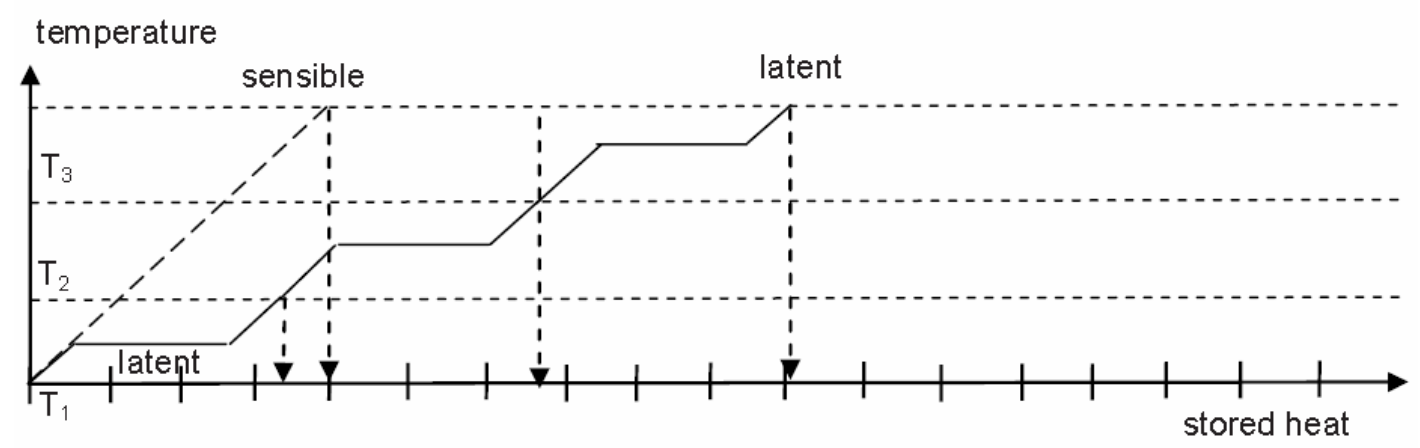

(b)

Fig. 12. Comparison of stored heat between sensible heat storage and latent heat storage [89]: (a) With a single PCM; (b) With cascaded latent heat storage. 

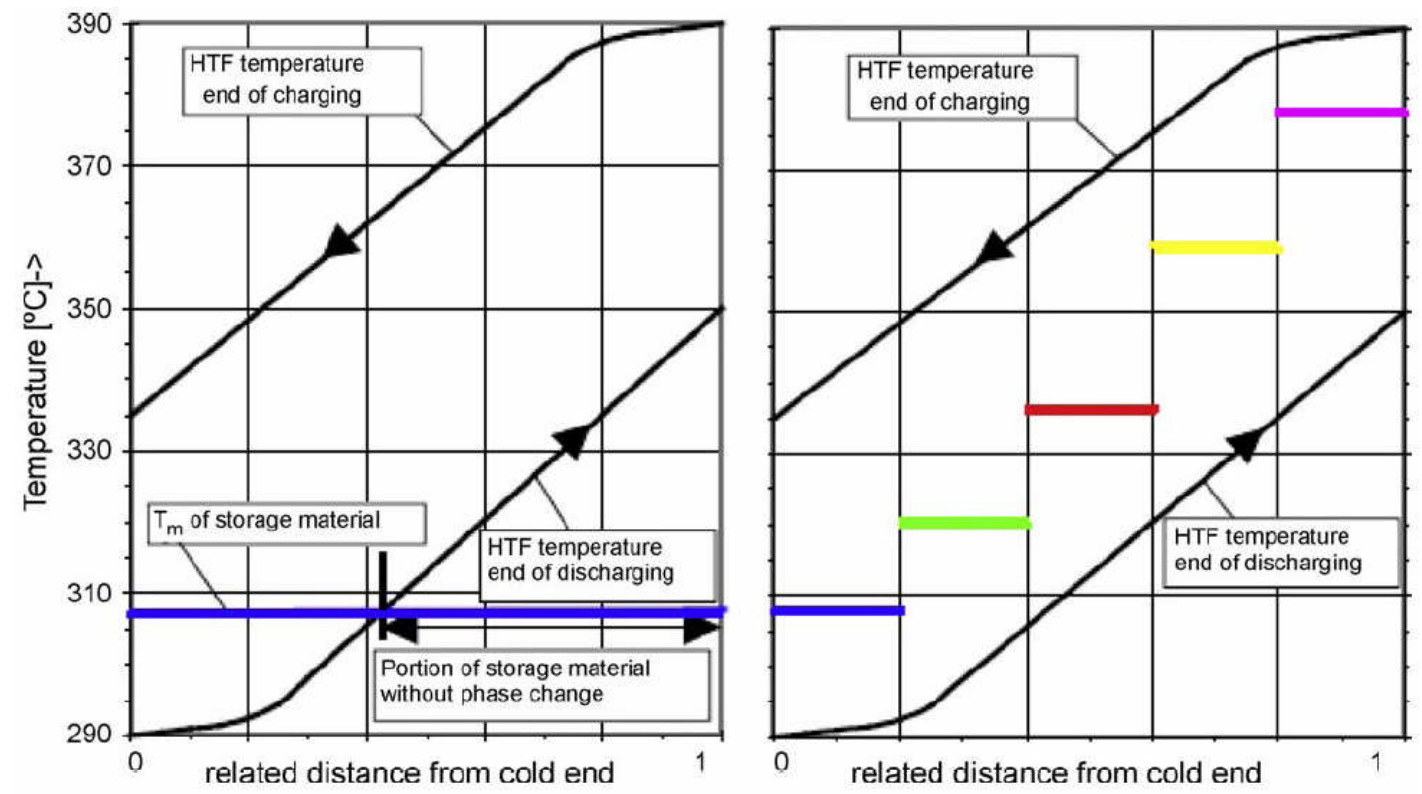

Fig. 13. Comparison between a single-stage storage system and a five-stage cascaded storage system [70, 59]. 